\title{
Investor-State Dispute Settlement and the Future of the Precautionary Principle
}

\author{
Haydn Davies* \\ Birmingham City University, UK
}

\begin{abstract}
The proliferation of bilateral investment treaties and investment chapters in trade megatreaties and the associated increase in the preference of investors for investor-state dispute settlement has given rise to concerns that the regulatory sovereignty of both developed and developing states might be compromised. In response to these concerns many trade agreements (including the recently concluded Comprehensive Economic Trade Agreement between the European Union (EU) and Canada) have incorporated provisions designed to protect the regulatory sovereignty of nation states, especially in relation to labour standards, public health, phytosanitary and environmental protection. This paper examines the nature and scope of environmental protection measures in investment chapters and attempts to analyse the extent to which these measures will, in practice, prevent challenges by investors seeking to chill or prevent environmental regulations which might threaten their investments. The analysis concentrates particularly on measures based on the precautionary principle and uses the current EU restrictions on neonicotinoid pesticides as a case study. The paper concludes that the measures included in investment chapters designed to prevent such challenges by investors will not necessarily achieve the desired level of protection for environmental regulatory sovereignty.
\end{abstract}

\section{CONTENTS}

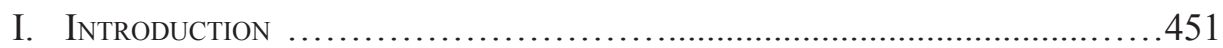

II. Investment Chapters and the Balance Between Private and Public INTERESTS IN AN ENVIRONMENTAL CONTEXT ....................................455

III. Investor-State Dispute Settlement and the Threat to Environmental SOVEREIGNTY ..................................................................4 460

IV. The Precautionary Principle - A Brief Background ..........................468

* Associate Professor and Director of Research at the School of Law at Birmingham City University, UK; Assistant Vice-Chair of the UK Environmental Law Association. PhD in Biochemistry (University College, Cardiff, 1988), LLB (University of Central England, 1999) BSc Biochemistry (University College, Cardiff, 1983). He can be reached at haydn.davies@bcu.ac.uk. 
V. The Neonicotinoids Restrictions in the European Union and how they Might Fare under the Proposed TTIP Investment Protection

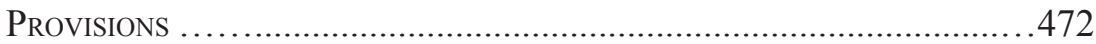
A. Establishing Standing: Investors, Investments and Covered Investments 475

B. Fair and equitable treatment 478

C. Expropriation 480

D. The Environment Chapter in the TTIP 483

E. Influence of the EU Commission's Proposed Independent Arbitral Tribunal 484

VI. CONCLUSION. 485 


\section{INTRODUCTION}

Free trade agreements can be traced back to the ancient empires which existed before the Common Era. ${ }^{1}$ However, the heyday of trade expansion came in the nineteenth century when the transport innovations of the industrial revolution, combined with Empire, and an adherence to laissez-faire economics - particularly in Great Britain - opened up enormous trade opportunities across the world. ${ }^{2}$ An early example of bilateralism, which featured the now-familiar most favoured nation status, was the Cobden-Chavalier agreement of 1860 between Great Britain and France. This led to a series of similar European agreements which created something of a golden era of trade in Europe. Unfortunately this was short-lived; an economic depression in the 1870 s ushered in a period of increasing protectionism which was ultimately to lead to great instability and nationalism culminating in a half-century of economic and military conflict in the twentieth century. ${ }^{3}$ Following World War II, the General Agreement on Tariffs and Trade - the first major multilateral trade agreement and the forerunner of the $\mathrm{WTO}^{4}$ - was created in 1948, having been salvaged from the failed attempt to create an international trade organisation at a conference of states in the Cuban capital in 1947..$^{5}$

GATT, and later, the WTO, facilitated the growth of the global economy in the later twentieth and twenty-first centuries, and offered an independent dispute settlement service in the form of the WTO's dispute settlement body and appellate panel. These offered a means of settlement of trade disputes that avoided, initially at least, some of the political and diplomatic hurdles presented by statestate negotiation. However, the WTO seems to have become a victim of its own success. Viviane de Beaufort takes the view that despite its considerable success in attempting to broker agreements between 159 states, progress at the WTO has foundered on: "confrontations between states"; the increasingly complex nature of the negotiations which have moved from concerns with tariffs to complex technical matters such as phytosanitary protection and intellectual property; and the rise of "concerns on sovereignty." ${ }^{6}$ As a result multilateralism on the WTO model has suffered a decline in popularity originating in "a general lack of enthusiasm from states and ... WTO governance issues." " Consequently states have moved towards bilateral or multilateral free trade agreements, including the recent socalled Mega-Treaties, brokered without direct input from the WTO. A number of such agreements also contain provisions on investment and these tend to follow established patterns in bilateral investment treaties (BITs), and commonly define

1 World Trade Organisation, World Trade Report 2011, 49, available at https://www. wto.org/english/res_e/booksp_e/anrep_e/world_trade_report11_e.pdf (last visited May 4, 2016).

Id.

Id. at 50-51.

Which replaced GATT in 1995.

See The GATT years: from Havana to Marrakesh, World Trade Organisation, https:// www.wto.org/english/thewto_e/whatis_e/tif_e/fact4_e.htm (last visited May 4, 2016)

6 Viviane de Beaufort, The European Union and the $\bar{N} e w$ Face(s) of International Trade, 1 Int. Bus. L. J. 39, 41 (2015).

7 Id. 
the terms for investments between states, make provision for most-favoured nation status, define what is meant by fair and equitable treatment, prohibit expropriation and may even make provision for dispute settlement, which may permit an investor to sue a host state directly.

In recent times, the United States has been particularly active in embracing this model of trade and, since its first free trade agreement with Israel in 1985, is now party to 20 free trade agreements, ${ }^{8}$ including the North American Free Trade Agreement (NAFTA), ${ }^{9}$ and the recently concluded Trans-Pacific Partnership (TPP). ${ }^{10}$ It is also a party to 42 bilateral investment treaties ${ }^{11}$ as well as 52 trade and investment framework treaties. ${ }^{12}$ While the use of BITs by the United States may appear impressive it is dwarfed by Germany's 135 (of which 32 are in force) and the United Kingdom's 106 (96 in force). In fact, the proliferation of this type of agreement worldwide has been such that the United Nations Conference on Trade and Development puts the current number of BITs at 2948, of which 2317 are in force. ${ }^{13}$ The proliferation of BITs was near-exponential between 1970 (five agreements) and the peak in 1996 (221 agreements). Since then, the scope for new BITs has declined with only 11 BITs concluded in 2013. ${ }^{14}$

This increase of BITs and investment chapters in free trade agreements is coupled with a spectacular increase of case load in investor-state dispute settlement (ISDS) fora. The last summary of the case load statistics for the International Centre for the Settlement of Investment Disputes (ICSID) indicated that 52 applications were currently registered. Just a decade earlier, in 2005, the figure was approximately half that (at 27 applications), and in 1995 was a mere three applications. ${ }^{15}$ In the years 1972 to 1994, ICSID applications totalled only 32; by December 2015 this total had risen to 549. This has occurred against the background of a rise in preference for arbitration generally as evidenced by the growth in other arbitral fora. ${ }^{16}$

8 For a list of the U.S. free trade agreements see https://ustr.gov/trade-agreements/freetrade-agreements (last visited May 4, 2016).

$9 \quad$ North American Free Trade Agreement, US-Can.-Mex., Dec.17, 1992, 32 I.L.M 289 (1993), available at https://ustr.gov/trade-agreements/free-trade-agreements/northamerican-free-trade-agreement-nafta.

10 A conglomerate of 12 states: Australia, Brunei, Canada, Chile, Japan, Malaysia, Mexico, New Zealand, Peru, Singapore, USA and Vietnam. At the time of writing TPP is yet to be ratified. Trans-Pacific Partnership text released Jan. 26, 2016 following legal scrub, available at https://ustr.gov/tpp/.

11 For a list of U.S. bilateral investment treaties, see http://tcc.export.gov/Trade Agreements/Bilateral_Investment_Treaties/index.asp (last visited May 4, 2016).

12 For a list of U.S. trade and investment framework treaties, see https://ustr.gov/tradeagreements/trade-investment-framework-agreements (last visited May 4, 2016).

13 See UNCTAD, Investment Policy Hub, http://investmentpolicyhub.unctad.org/IIA (last visited May 4, 2016).

14 Figures compiled from data from the ICSID Database of Bilateral Investment Treaties, available at https://icsid.worldbank.org/apps/ICSIDWEB/resources/Pages/BilateralInvestment-Treaties-Database.aspx (last visited May 31, 2016).

15 The ICSID Caseload - Statistics, International Centre for the Settlement of InVESTMEnT Disputes, (Issue 2016-1) at 7, Chart 1, available at https://icsid.worldbank. org/apps/ICSIDWEB/resources/Documents/ICSID\%20Web\%20Stats\%202016-1\%20 (English)\%20final.pdf.

16 By way of illustration, business of the International Court of Arbitration of the International Chamber of Commerce has grown from 529 cases in 1999 to 801 in 2015 [See 
The reasons for the rise in popularity in BITs and the introduction of investment chapters in free trade agreements, particularly the recent Mega-Treaties are not difficult to find. There are distinct advantages to states in brokering agreements directly and, as Caroline Foster has pointed out, such agreements "encourage and support international commercial private actors' freedoms to invest, disinvest, repatriate capital, buy and sell goods and services, employ, navigate, exploit communal resources, and take business decisions." ${ }^{17}$ As such, both developing and developed states favour investment agreements; developing states, because they facilitate foreign direct investment, and developed states, because they offer an attractive trading platform for private actors - invariably economically important multinational corporations - amongst others, with the introduction of an ISDS mechanism which avoids the diplomatic and political vagaries of state-state settlement..

However, there are some distinct disadvantages to ISDS. In particular, it permits aggrieved investors to take host states directly to international arbitration; it is not necessarily the case that the investor need first exhaust domestic remedies ${ }^{18}$ especially

Statistics, International CHAmber of COMmerce, available at http://www.iccwbo. org/Products-and-Services/Arbitration-and-ADR/Arbitration/Introduction-to-ICCArbitration/Statistics/ (last visited May 4, 2016)], international cases of the Arbitration Institute of the Stockholm Chamber of Commerce have grown (albeit irregularly) from 56 cases in 2005 to 101 in 2015 [See SCC Statistics, Arbitration Institute of The Stockholm Chamber of Commerce 2015, available at http://www.sccinstitute. com/statistics/ (last visited May 4, 2016)]; the China International Economic and Trade Arbitration Commission, known also since 2000 as the Arbitration Court of the China Chamber of International Commerce case load involving 'foreign' disputes has varied between 331 and 562 cases per annum between 2006 and 2015, though these are not ISDS cases. However, total case load (including domestic disputes) has risen from 981 cases in 2006 to 1968 cases in 2015 [See Statistics, ChinA InTERnational Economic and Trade Arbitration Commission available at http://www.cietac.org/index. $\mathrm{php} ? \mathrm{~m}=$ Page $\& \mathrm{a}=\mathrm{index} \& \mathrm{id}=40 \& \mathrm{l}=\mathrm{en}$ (last visited April 15, 2015)]. These supplement and complete with the longer established centres in London and Paris.

17 Caroline Foster, A New Stratosphere? Investment Treaty Arbitration as 'Internationalized Public Law', 64 InT'L \& Comp L.Q. 461, 462 (2015) (citing T.W. Waelde). For a wider treatment of the advantages and disadvantages of ISDS see Ahmad Ali Gouri, The Evolution of Bilateral Investment Treaties, Investment Treaty Arbitration and International Investment Law, INT. A.L.R. 14, 189-204 (2011); Mojtaba Dani \& Afshin Akhtar-Khavari, The Uncertainty of Legal Doctrine in Indirect Expropriation Cases and the Legitimacy Problems of Investment Arbitration, 22 WIDENER L. REV. 1 (2016); Rudolf Dolzer, Fair and Equitable Treatment: Today's Contours, 12 SANTA Clara J. InT'L L. 7 (2013); Becky L. Jacobs, Perplexing Paradox: "De-Statification" of "Investor-State” Dispute Settlement? 30 Emory InT'L L. Rev. 17 (2015-2016); Ivan Pupolizio, The Right to an Unchanging World Indirect Expropriation in International Investment Agreements and State Sovereignty, 10 Vienna J. on InT'L Const. L. 143 (2016); Gus Van Harten \& Martin Loughlin, Investment Treaty Arbitration as a Species of Global Administrative Law, 17 Eur. J. INT'L 121-50 (2006).

18 E.g. Article 26 of the ICSID Convention states that "A Contracting State may require the exhaustion of local administrative or judicial remedies as a condition of its consent to arbitration under this Convention" (emphasis added) see Convention on the Settlement of Investment Disputes between States and Nationals of Other States, Mar. 18, 196517 U.S.T. 1270, 575 U.N.T.S. 159, art. 26, available at https://icsid.worldbank.org/apps/ ICSIDWEB/icsiddocs/Documents/ICSID\%20Convention\%20English.pdf (last visited May 4, 2016). [hereinafter ICSID Convention] (Note that the preamble to the 2000 
if they consider that seeking such remedies might be futile. ${ }^{19}$ Once at ICSID, or a similar forum, the nature of the ISDS that follows is profoundly different from normal "private" arbitration, in that one of the parties (the state) is constrained by public interest considerations that do not affect the other. This use of arbitration has been described as "internationalized public law" 20 and, in effect, takes the established principles of domestic public law and places them in an international arbitration forum which is not necessarily well suited for the purpose. Arbitration was developed for private investors as a relatively swift alternative to contentious litigation where the remedy was decided according to the dictates of commercial expediency and with a view to maintaining the commercial relationship. The rules of natural justice, due process, stare decisis and the requirements of transparency (i.e. justice being seen to be done) are secondary considerations. Perhaps most controversial is the fact that decisions of ICSID tribunals are not subject to appeal, ${ }^{21}$ apart from an annulment procedure which can overturn a decision on limited grounds. ${ }^{22}$ This limitation does not apply to disputes involving non-parties who may take advantage of the ICSID Additional Facility rules; such decisions are subject to appeal. ${ }^{23}$

The paper will examine just one aspect of ISDS, but one which has profound implications for regulatory sovereignty in nation states. At issue is the question of whether BITs and investment chapters in recent Mega-Treaties permit investors to challenge regulatory decisions on the basis, inter alia, that they amount to a lack of fair and equitable treatment for investors or are tantamount to expropriation of their assets. This is most likely to arise where regulation is based on an interpretation of scientific data (often related to public health or environmental protection) which is susceptible to different regulatory responses. In the European Union such decisions are often predicated on the precautionary principle - which is an important element of European primary law $^{24}$ - whereas in the United States and Canada,

BIT between Croatia and the United States (signed by President Clinton) states that international arbitration is available to investors as an alternative to domestic courts.)

19 See Philip Morris Products S.A. and Abal Hermanos S.A. v. Oriental Republic of

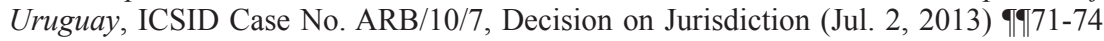
where the arbitral panel analyses why the claimant had no need to exhaust domestic remedies before proceeding to international ISDS.

20 Foster, supra note 17.

21 See ICSID Convention, supra, note 18, art. 53(1) "The award shall be binding on the parties and shall not be subject to any appeal or to any other remedy except those provided for in this Convention."

22 Id. art. 52. The grounds of annulment are "(a) that the Tribunal was not properly constituted; (b) that the Tribunal has manifestly exceeded its powers; (c) that there was corruption on the part of a member of the Tribunal; (d) that there has been a serious departure from a fundamental rule of procedure; or (e) that the award has failed to state the reasons on which it is based."

23 For example, the award in Metalclad Corporation v. United Mexican States, ICSID Case No. ARB(AF)/97/1 (Aug. 30, 2000) was subject to appeal in the Supreme Court of British Columbia following considerable disquiet about the scope of that decision and its effect on Mexican municipal sovereignty. Although Mexico is not a signatory to the ICSID Convention, the appeal was possible because Mexico had nonetheless elected to use ICSID (under the Additional Facility Rules) to determine its NAFTA dispute over a hazardous waste site with U.S. and Canadian investors in Metalclad Inc.

24 Treaty on the Functioning of the European Union (Consolidated Version), 2008 O. J. (C 115), 47, art. 191(2). 
the precautionary principle is viewed with suspicion if not outright hostility. ${ }^{25}$ Should an arbitral tribunal be tasked with having to decide whether the regulatory decision is a proportionate one, this could embroil it, not so much in an assessment of the scientific evidence per se, but in an assessment of the relative merits of the precautionary principle compared to the cost-benefit approach favoured elsewhere in the world. In other words an assessment of how uncertainty in scientific evidence should best be built into regulatory decision-making. This, in effect, places a tribunal in the position of adjudicating in the public interest, a role normally associated with a fully constituted judiciary. Moreover, its decision, if made according to normal arbitration principles, could have the effect of subjugating national sovereignty to private commercial interest. It might also permit one state to use its private sector investors to "adjust" or "chill" regulation in another. This is certainly a fear among some in the European Parliament as it continues to debate the negotiation of the Transatlantic Trade and Investment Partnership (TTIP) between the United States and the European Union. ${ }^{26}$ This paper attempts to assess the reality of that fear.

However, rather than discuss this issue in purely abstract and theoretical terms, an attempt has been made to analyse the possibilities through a real-life and current issue, namely the European Commission's restriction on the use of neonicotinoid insecticides. Hence this paper will assess what the possibilities might be were an investor to challenge this restriction under the terms of the proposed (though partly hypothetical $)^{27}$ investment chapter of TTIP and to reach some tentative conclusions on the reality of the threat to regulatory sovereignty in respect of the precautionary principle.

\section{Investment Chapters and the Balance Between Private and Public Interests in an Environmental Context}

The European Commission has been at great pains to reassure concerned parties (including the "European Parliament, Member States, national parliaments and

25 See e.g. Cass R. Sunstein, Laws of Fear: Beyond the Precautionary Principle (2005).

26 Pressure from a centre-left coalition of members of the European Parliament resulted in the postponement of a vote on TTIP in the EU Parliament in June 2015 owing to the vast number of tabled amendments [See http://www.europarl.europa.eu/us/en/news_events/ news/news_2015/newsletter_articles/newsletter_articles_june_2015/ttip_overview.html (last visited May 31, 2016)]. Among the amendments put forward by this coalition was Amendment 27: ".. to ensure that foreign investors are treated in a non-discriminatory fashion and have a fair opportunity to seek and achieve redress of grievances, while benefiting from no greater rights than domestic investors; to oppose the inclusion of investor-state dispute settlement (ISDS) in TTIP, as other options to enforce investment protection are available, such as domestic remedies ..." (emphasis added).

27 The putative text of the TTIP is not generally made available to interested parties outside the EU Commission and the U.S. State Department. However, the European Commission has recently redrafted the proposed investment chapter and published it online, albeit in different stages of completion, see infra note 128 and associated text. The Commission draft is available at http://trade.ec.europa.eu/doclib/docs/2015/september/ tradoc_153807.pdf (last visited May 31, 2016). 
stakeholders" 28 ) that any ISDS arrangements in TTIP will not affect regulatory sovereignty. In its press release in September 2015 on new proposals for an "Investment Court System for TTIP and other EU trade and investment negotiations" it reassured readers that "governments' right to regulate would be enshrined and guaranteed in the provisions of the trade and investment agreements." 29

The Commission was perhaps well-advised to issue this reassurance since scrutiny of the operation of investment chapters in existing agreements, by analysis of the arbitral decisions that have emerged from them, could lead an analyst to a rather different conclusion. This Part will examine the general nature of the protections for environmental regulatory sovereignty in typical investment agreements, proposed and extant, before examining, in Part III, some of the arbitral decisions which have engaged with these types of provisions.

Modern model investment treaties such as the 2012 U.S. Model BIT ${ }^{30}$ contain, at least on the face of it, built-in protection of the ability of states to regulate without interference from external investors. For example, Article 12 of the 2012 U.S. Model BIT concerns "Investment and Environment" and makes impermissible any attempts by states to:

waive or otherwise derogate from or offer to waive or otherwise derogate from its environmental laws ... in a manner that weakens or reduces the protections afforded in those laws, or fail to effectively enforce those laws through a sustained or recurring course of action or inaction, as an encouragement for the establishment, acquisition, expansion, or retention of an investment in its territory. ${ }^{31}$

This recognises the well-established fact that weakening environmental regulatory standards can have the effect of distorting trade and seeks to avoid a race to the bottom in terms of environmental protection. ${ }^{32}$

The 2012 U.S. Model BIT also recognises the sovereignty of states in promulgating environmental regulation. Article 12(5) states that:

Nothing in this Treaty shall be construed to prevent a Party from adopting, maintaining, or enforcing any measure otherwise consistent with this Treaty that it considers appropriate to ensure that investment activity in its territory is undertaken in a manner sensitive to environmental concerns. ${ }^{33}$

28 Press Release, European Commission, Commission Proposes New Investment Court System for TTIP and other EU Trade and Investment Negotiations, IP/15/5651 (Brussels, Sept. 16, 2016), available at http://europa.eu/rapid/press-release_IP-15-5651_en.htm.

$29 \quad$ Id.

302012 U.S. Model Bilateral Investment Treaty, available at http://www.state.gov/documents/organization/188371.pdf.

31 Id. art. 12(2). This text is incorporated, for example into Article 12(1) of the United States-Uruguay Bilateral Investment Treaty agreed in 2005, available at http://www. state.gov/e/eb/ifd/bit/117402.htm.

32 Though it must be said that this protection is a relatively recent addition to the U.S. Model BIT and this provision does not feature in the older BIT agreements entered into by the United States, see id.

33 See United States-Uruguay Bilateral Investment Treaty, supra note 31, art. 12(2). 
Thus treaties based on the 2012 U.S. Model BIT not only attempt to protect the sovereignty of states in maintaining, adopting and enforcing environmental regulation but also ensure that states do not weaken protection in order to attract investment.

The Comprehensive Economic and Trade Agreement (CETA) between Canada and the European Union, concluded in September $2014,{ }^{34}$ is viewed by many as presaging the likely final contents of the TTIP and has drawn on existing model BITs (including the 2012 U.S. Model BIT) for many of its provisions. ${ }^{35}$ CETA makes provision for investment protection ${ }^{36}$ which is similar to existing model BIT texts, though the investment chapter was significantly modified following legal analysis such that:

Canada and the EU will strengthen the provisions on governments' right to regulate; move to a permanent, transparent, and institutionalised dispute settlement tribunal; revise the process for the selection of tribunal members, who will adjudicate investor claims; set out more detailed commitments on ethics for all tribunal members; and agree to an appeal system. ${ }^{37}$

Hence the principal changes to the investment chapter in CETA were to create a bespoke Tribunal and Appellate Tribunal for the purposes of investor-state dispute settlement, including bespoke rules for the appointment of members of the arbitration and appellate tribunals. This is in contrast to the original text of CETA which drew on the existing services of ICSID. The new version makes use of certain of the rules of the ICSID Convention and of the ICSID Secretariat's services but the arbitration hearings themselves will take place outside the ICSID system. This change was made to assuage some of the concerns, particularly in Europe, over the appointment and independence of ICSID arbitrators and the unavailability of appeal against ICSID arbitration decisions under Article 53(1) of the ICSID Convention.

In terms of CETA's protection of environmental regulation in state parties' territories, the investment chapter makes several concessions. Under Section B of CETA (Market Access), ${ }^{38}$ the following do not constitute a denial of market access for the purposes of investment:

(a) a measure concerning zoning and planning regulations affecting the development or use of land, or another analogous measure

34 Though still to be signed and ratified by the parties as of June 10, 2016. The document has undergone legal analysis in the European Union, the text of which was released in December 2015 [See In Focus: Comprehensive Economic and Trade Agreement (CETA), http://ec.europa.eu/trade/policy/in-focus/ceta/index_en.htm (last visited June 10, 2016)]. The consolidated text, issued on February 29, 2016 is available at http:// ec.europa.eu/trade/policy/in-focus/ceta/index_en.htm.

35 Cf. 2012 U.S. Model Bilateral Investment Treaty, supra note 5, art. 4 and Comprehensive Economic and Trade Agreement, supra note 8, art. 24.1 on the definition of "environmental law".

36 Comprehensive Economic and Trade Agreement, supra, note 34, ch. 8..

37 Joint statement by Cecilia Malmström, EU Commissioner for Trade, and Chrystia Freeland, Minister of International Trade of Canada, Feb. 29, 2016, available at http://trade. ec.europa.eu/doclib/docs/2016/february/tradoc_154330.pdf.

38 Comprehensive Economic and Trade Agreement, supra note 34, arts. 8.4 and 8.5. 
(b) $\ldots$

(c)

(d) a measure seeking to ensure the conservation and protection of natural resources and the environment, including a limitation on the availability, number and scope of concessions granted, and the imposition of a moratorium or ban; 39

Similarly, for the purposes of Section D of CETA (Investment Protection), ${ }^{40}$ which includes the provisions for fair and equitable treatment, compensation, expropriation, transfers and subrogation, ${ }^{41}$ a clarification is included at the beginning of the section:

For the purpose of this Chapter, the Parties reaffirm their right to regulate within their territories to achieve legitimate policy objectives, such as the protection of public health, safety, the environment or public morals, social or consumer protection or the promotion and protection of cultural diversity. ${ }^{42}$

The recently agreed TPP uses similar language in its investment chapter in relation to performance requirements:

Provided that such measures are not applied in an arbitrary or unjustifiable manner, or do not constitute a disguised restriction on international trade or investment, paragraphs 1(b), 1(c), 1(f), 2(a) and 2(b) shall not be construed to prevent a Party from adopting or maintaining measures, including environmental measures:

(i) necessary to secure compliance with laws and regulations that are not inconsistent with this Agreement;

(ii) necessary to protect human, animal or plant life or health; or

(iii) related to the conservation of living or non-living exhaustible natural resources. ${ }^{43}$

In relation to the TPP investment chapter as a whole, a general provision is included in Article 9.15:

Nothing in this Chapter shall be construed to prevent a Party from adopting, maintaining or enforcing any measure otherwise consistent with this Chapter that it considers appropriate to ensure that investment activity in its territory is undertaken in a manner sensitive to environmental, health or other regulatory objectives. ${ }^{44}$

Id. art. 8.4.2(a) (emphasis added).

Id. arts. 8.9-8.14.

Id. arts. 8.10-8.14 respectively.

Id. art. 8.9.1. (emphasis added).

Trans-Pacific Partnership, supra note 10, art. 9.9.3(d).

Id. art. 9.15 (emphasis added). 
The latest text of the investment chapter of the putative TTIP - though evidently incomplete $^{45}$ - is very similar to that of CETA, and also makes provision for a bespoke "Tribunal of First Instance" and a "permanent appeal Tribunal" for investor-state dispute settlement. ${ }^{46}$ It also contains articles, like CETA, relating to fair and equitable treatment, compensation, direct and indirect expropriation, transfers, subrogation and denial of benefits. ${ }^{47}$

Very similar protections for important public interest matters are to be found in other, more established, trade agreements such as the North American Free Trade Agreement (NAFTA) and these, unlike the texts of CETA, TTP and TTIP, have been the subject of arbitral decisions. For example, the preamble to NAFTA, inter alia, exhorts the three state parties to "STRENGTHEN the development and enforcement of environmental laws and regulations"48 and Article 1114 relates specifically to the investment chapter of the agreement and states that:

1. Nothing in this Chapter shall be construed to prevent a Party from adopting, maintaining or enforcing any measure otherwise consistent with this Chapter that it considers appropriate to ensure that investment activity in its territory is undertaken in a manner sensitive to environmental concerns.

2. The Parties recognize that it is inappropriate to encourage investment by relaxing domestic health, safety or environmental measures. Accordingly, a Party should not waive or otherwise derogate from, or offer to waive or otherwise derogate from, such measures as an encouragement for the establishment, acquisition, expansion or retention in its territory of an investment of an investor. If a Party considers that another Party has offered such an encouragement, it may request consultations with the other Party and the two Parties shall consult with a view to avoiding any such encouragement. ${ }^{49}$

On the face of it such provisions should prevent interference with the environmental regulatory sovereignty which states must exercise in the public interest and prevent the dismantling of existing regulation as a means of attracting foreign direct investment. However, the reality has not always reflected these expectations. Some arbitral decisions have suggested that investor interests can, in certain circumstances, outweigh the right of a state to exercise sovereignty. It is to these decisions that we now turn.

45 E.g. there are references to National Treatment and Most Favoured Nation Status at Annex II (Public Debt) to section 2, paragraph 2, see supra note 27. This paragraph refers to "Section 1: Liberalisation of Investments", but the full text of this section is not yet included in this Commission document; a separate document on investment protection is still under negotiation (see infra note 128).

46 Id. sec. 3 (Resolution of Investment Disputes and Investment Court System), arts 9 and 10 respectively.

47 Id. sec. 2 (Investment Protection), arts 3, 4, 5, 6, 8 \& 9 respectively.

48 North American Free Trade Agreement, supra note 9, Preamble.

49 Id. ch. 11, part Five (Investment, Services and Related Matters), art. 1114 (emphasis added). 


\section{Investor-State Dispute Settlement and the Threat to ENVIRONMENTAL SOVEREIGNTY}

Most ISDS proceedings have taken place under the auspices of the ICSID and a number of these have involved challenges based on attempts - at least on the face of it - to protect the environment or to preserve local sovereignty in respect of activities perceived to be environmentally unacceptable or contrary to local or national public health imperatives.

Perhaps the most controversial of these was the Metalclad arbitration, issued in August 2000 and heard under the Additional Facility rules of the ICSID Convention..$^{50}$ These rules were applied owing to the fact that Mexico, the state party, was not a party to the ICSID convention but had opted to use ICSID as a forum to determine a dispute relating to the construction and operation of a hazardous waste facility in the La Pedrera valley near Guadalcazar in the State of San Luis Potosi in southern Mexico. ${ }^{51}$ The arbitration was required to determine whether the Mexican municipal authorities had acted in such a way, in preventing the operation of the site (in response to strong local opposition), as to contravene Articles 1105 and 1110 of the NAFTA which state:

Article 1105(1):

Each Party shall accord to investments of investors of another Party treatment in accordance with international law, including fair and equitable treatment and full protection and security.

$\ldots$

Article 1110:

No Party may directly or indirectly nationalize or expropriate an investment of an investor of another Party in its territory or take a measure tantamount to nationalization or expropriation of such an investment ("expropriation"), except:
(a) for a public purpose;
(b) on a non-discriminatory basis;
(c) in accordance with due process of law and Article 1105(1); and
(d) on payment of compensation

In short, the U.S. and Canadian investors in Metalclad were seeking to show that the lack of transparency in the operation of the Mexican regulatory system relating to hazardous waste sites, and the decision of the local municipality to create a nature reserve which included the entire site (thereby rendering it inoperable), amounted to a lack of fair and equitable treatment and to measures tantamount to expropriation.

The decision in relation to Article 1105(1) was based on the fact that there was considerable uncertainty on the part of the Mexican federal, state and municipal

50 Metalclad Corporation v. The United Mexican States, ICSID Case No. ARB(AF)/97/1, Award (Aug. 30, 2000).

51 Mexico was able to take advantage of this procedure by virtue of Article 1120(1)(b) of the NAFTA, to which Mexico is a signatory. At the time of writing Mexico remains a non-signatory to the ICSID Convention. 
authorities as to which of them was in fact responsible for the permitting of hazardous waste facilities. ${ }^{52}$ Metalclad had legitimately, and in good faith, relied on federal assurances about the legality of the construction and operation of the site. The absence of regulatory clarity, and uncertainty as to practice and procedure at the various levels of governance amounted to a lack of transparency. Given the strength of local opposition ${ }^{53}$ it is perhaps understandable that the municipal authority so assiduously tried to prevent construction and operation of the plant. Nonetheless, the uncertainty unquestionably affected Metalclad's ability to make decisions about, and to realise, their investment. The fact that ultimately this uncertainty resulted in an arbitral decision which compensated foreign investors at the expense of local autonomy may be seen as unfortunate, but Metalclad's treatment was arguably unfair and inequitable treatment by the standards of international law, particularly as they had engaged extensively with domestic procedures in an attempt to resolve the issue before turning to ICSID.

However, aspects of the panel's comments on the Article 1110 infringement were much more controversial. Much of the decision appeared to follow logically from the Article 1105 finding, on the basis that such a degree of opacity in the regulatory and legal process was not only unfair and inequitable treatment, but on such a serious scale as to qualify also as a measure tantamount to expropriation. However, the panel went further and considered the state governor's decision to issue an Ecological Decree which encompassed the site as part of the Article 1110 analysis:

... the Tribunal also identifies as a further ground for a finding of expropriation the Ecological Decree issued by the Governor of SLP on September 20, 1997. This Decree covers an area of 188,758 hectares within the "Real de Guadalcazar" that includes the landfill site, and created therein an ecological preserve. This Decree had the effect of barring forever the operation of the landfill. ${ }^{54}$

The Tribunal need not decide or consider the motivation or intent of the adoption of the Ecological Decree. Indeed, a finding of expropriation on the

52 Metalclad Corporation v. The United Mexican States, supra note 50, qT 78-101. The tribunal found that responsibility rested solely with the federal authorities and that the municipality's refusal to grant building permits on the basis of environmental considerations, rather than restricting their scrutiny to "appropriate construction considerations" (Id. at 86) amounted, in effect, to an ultra vires exercise of power. It could be argued of course, that "environmental impact considerations" are legitimate construction considerations when assessing physical construction or site defects. After all, the physical construction of a site itself has an impact on the environment and a full environmental impact assessment should take account of construction as well as subsequent operation of a landfill site. Furthermore, if an environmental impact assessment does not adequately analyse the suitability of the site itself (in terms of geological suitability, treatment of leachate to water and land, emissions to air and so forth) then how can the site itself be said to suitable, and hence free from defect. However, the Tribunal chose to construe these terms more narrowly and, unlike the author, had the benefit of hearing or reading both parties' expert evidence in full.

$53 \quad$ Id. 991.

54 Id. 109. 
basis of the Ecological Decree is not essential to the Tribunal's finding of a violation of NAFTA Article 1110. However, the Tribunal considers that the implementation of the Ecological Decree would, in and of itself, constitute an act tantamount to expropriation. ${ }^{55}$

This was to attract considerable informed criticism and adverse judicial treatment in the aftermath. Many commentators considered that the Tribunal - which was led by no less a figure than Professor Sir Elihu Lauterpacht, CBE, QC - had construed the term "indirect measures tantamount to expropriation" unacceptably widely and in such a way as to trespass on the legitimate exercise of state sovereignty in environmental matters. Professor Phillipe Sands has characterised the Tribunal as taking "a very broad approach to the definition of expropriation" 56 and has written elsewhere that such decisions represent a worrying and retrograde development in the requirement to balance the interests of investment with those of environmental protection. $^{57}$

The decision received judicial scrutiny at the hands of Judge David F. Tysoe of the Supreme Court of British Columbia. ${ }^{58} \mathrm{He}$ reviewed the reasoning of the Tribunal and concluded that the Metalclad Tribunal had exceeded its jurisdiction when deciding whether the Mexican government had contravened NAFTA Article 1105 ostensibly by importing the concept of transparency into the text of the Article as one of the objectives of the NAFTA. In Tysoe J.'s view the international law concept of fair and equitable treatment does not incorporate the concept of transparency and the Tribunal exceeded its jurisdiction in importing it. ${ }^{59}$ The question of transparency was thus beyond the scope of the submission to arbitration "because there are no transparency obligations contained in Chapter 11." ${ }^{60}$ In relation to Article 1110, Tysoe J. considered that the Tribunal's Article 1105 analysis had "infected its analysis of Article 1110." ${ }^{61}$ Thus since the decision on Article 1105 had improperly taken account of transparency and this was then used as the basis for deciding the Article 1110 issue, this too was beyond the scope of its jurisdiction for the same reason.

\footnotetext{
Id. $\mid 111$ (emphasis added).

Philippe SAnds, Lawless World 133 (2005).

57 Philippe Sands, Litigating Environmental Disputes: Courts, Tribunals and the Progressive Development of International Environmental Law, OECD Forum on International Investment (27-28 $8^{\text {th }}$ March, 2008) at footnotes 38-41 and associated text, available at http://www.oecd.org/investment/globalforum/40311090.pdf. Note that at footnote 38 Sands indicates that the Metalclad Tribunal decision had not been published at the time of his writing.

58 It was stated earlier that arbitration under the ICSID Additional Facility rules are not subject to Article 53(1) of the ICSID Convention (which forbids appeals against decision made under the ICSID Rules) and hence may be appealed in a suitable national court. Thus because the Metalclad arbitration had been held in Vancouver, the Supreme Court of British Columbia had jurisdiction to hear the appeal under the terms of British Columbia's International Commercial Arbitration Act, R.S.B.C. 1996 c. 233. See The United Mexican States v. Metalclad Corporation \& Attorney General of Canada \& La Procureure Générale du Québec on Behalf of the Province of Québec - intervenors [2001] BCSC 664.

$59 \quad$ Id. $₫ \uparrow$ 67-76.

$60 \quad I d .972$.
}

${ }^{61} \quad I d .978$. 
Turning to the question of whether the passing of the Eco-Decree amounted to a measure tantamount to expropriation, Tysoe, J. was not able to conclude that the Tribunal had been patently unreasonable in reaching its decision. However, he did conclude that the definition of expropriation used by the Tribunal was "sufficiently broad to include a legitimate rezoning of property by a municipality or other zoning authority." ${ }^{62}$ However, given that the definition used was a matter of law, the resulting conclusion was one with which Tysoe J. was "not entitled to interfere under the International CAA." 63

The importance of the Metalclad decision lies partially in its demonstration of the power of arbitral decision-making vis-à-vis sovereign interests and in the potential of international trade law principles to influence the shape and form of local and national regulatory measures.$^{64}$ However, the subsequent use (or non-use) of the decision in other arbitral disputes serves also to illustrate the unpredictability and relative capriciousness of such decisions and the uncertainty that governments might face in designing and enforcing regulatory measures such that they do not fall foul of investor challenges or attempts to "chill" the regulatory process.

What then, is the legacy of the Metalclad decision on fair and equitable treatment and expropriation, and to what extent has it been followed subsequently by other tribunal panels? This is not such a straightforward question to answer for a number of reasons. Firstly, arbitral tribunals decide each case on the facts before them and the terms of the underlying agreement and hence the common law doctrine of stare decisis is not appropriate. Secondly, there is no requirement for ICSID arbitral awards to be published - and many are not, or are published as excerpts only. ${ }^{65}$ Thus it is not possible in many cases to find out whether, or the extent to which, the Metalclad interpretation of "tantamount to expropriation" was relied upon. Thirdly, different investment agreements between states take different approaches to fundamental state-investor relations such as most-favoured nation treatment, fair and equitable treatment, expropriation and discrimination. Hence references to previous awards based on NAFTA will, at best, have persuasive authority, but may have none at all.

It is worth noting, however, that not long after the Metalclad decision was issued, the NAFTA rules were altered in respect of the meaning of fair and equitable treatment. The NAFTA Free Trade Commission adopted, on July 31, 2001, a Note of Interpretation entitled "Minimum Standard of Treatment in Accordance with International Law." ${ }^{\prime 66}$ It states, inter alia, that the interpretation of "... the concepts of 'fair and equitable treatment' and 'full protection and security' do not require treatment in addition to or beyond that which is required by the customary

\section{Id. 999.}

Id.

64 Though it should be noted in passing, in the interests of balance, that the tribunal's award of US $\$ 16.7 \mathrm{~m}$ against Mexico represented only $18.5 \%$ of the original claim of US\$90m Metalclad's projected profits were not awarded on the basis, inter alia, that the waste site had never operated as such.

65 Though in recent times there is a marked preference for full publication, probably in the interests of transparency and in an attempt to improve the public perception of the legitimacy of the decisions.

66 See Apotex Holdings Inc. v. United States of America, ICSID Case No. ARB(AF)/12/1, Award (Aug. 25, 2014) 99.3. 
international law minimum standard of treatment of aliens." This change may or may not have been passed in response to the Metalclad decision but at any rate should have made such a broad interpretation less likely in the future, at least where NAFTA-based arbitrations are concerned.

And yet, barely three years after Metalclad arbitration, Mexico found itself back at ICSID facing similar claims of lack of fair and equitable treatment and expropriation relating to another hazardous waste landfill site - this time far to the north-west in the Municipality of Hermosillo, in the State of Sonora in Mexico. ${ }^{67}$ This time the BIT between Spain and Mexico was the governing instrument and again it was dealt with under the ICSID Additional Facility rules. Notwithstanding the earlier criticism of Metalclad, the tribunal applied a similar analysis to that employed in Metalclad and reached essentially the same conclusions. ${ }^{68}$

The Metalclad decision arose again in Waste Management Inc., yet another ICSID case involving Mexico. ${ }^{69}$ This case also involved Article 1105(1) and Article 1110 claims against Mexico, again in the context of waste management, and again where local unrest played a part. The U.S. investor claimed that the failure of municipal authorities in Acapulco properly to cede a waste management concession amounted to "measures tantamount to expropriation." This had occurred in circumstances where local people had taken great exception to the imposition of new waste collection charges and the dismantling of existing systems (poorly regulated though they were) and had refused to cooperate - or pay. This resulted in the entire scheme becoming economically unviable.

The Waste Management Inc. Tribunal did refer to the Metalclad decision, and appeared to acquiesce in Justice Tysoe's characterisation of the interpretation of tantamount to expropriation as "extremely broad." 70 In the event, the Waste Management Inc. Tribunal did not need to engage with this interpretation as it considered that the waste concession had not been a "regulatory taking" (as in Metalclad) but had failed because it was economically unviable from the start. Thus the Metalclad issue could be evaded.

Expropriation also arose in the case of Lucchetti where a conservation order (Decree 258) was placed on an area including a pasta factory owned by an investor based in Chile. ${ }^{71}$ A follow-up decree (Decree 259), aimed at implementing the first decree stated:

\section{IT IS HEREBY DECREED:}

Article 1.- The municipal operating license granted by Municipal Resolution No. 6856-98-MDCH to Lucchetti Perú S.A. for its industrial plant situated at an unnumbered location on Avenida Prolongación Defensores del Morro, $20.5 \mathrm{~km}$ along the Panamericana Sur highway, Chorrillos, for the manufacture and sale of pasta is hereby revoked.

67 Tecmed Medioambientales Tecmed S.A. v. United Mexican States, ICSID Case No. $\mathrm{ARB}(\mathrm{AF}) / 00 / 2$, Award (May 29, 2003).

68 Id. \ๆ 95-174; Metalclad is cited at $₫ 113$ (footnote 125).

69 Waste Management Inc. v. United Mexican States, ICSID Case No. ARB(AF)/00/3, Award (Apr. 30, 2004).

$70 \quad$ Id. ๆ $153-4$ \& 159.

${ }^{71}$ Empresas Lucchetti S.A. v. Republic of Peru, ICSID Case No. ARB/03/04 (2005). 
Article 2.- The industrial establishment referred to in the preceding article shall be closed and entirely removed; this shall be done within a maximum of twelve months from the day following the publication of this Decree.

Evidently this entirely "closed and ... removed" the factory - a clearer example of expropriation would be difficult to imagine. However, given that it was for the purposes of environmental protection (i.e. in the public interest) and appeared nondiscriminatory in the sense that all outlets in that area were similarly affected, it would have been interesting to see how the Tribunal would have approached it. In the event Lucchetti's claim failed on technical grounds ${ }^{72}$ and the expropriation issue was never dealt with so we can only speculate on whether the Metalclad approach would have been invoked or not.

In 2012, the Metalclad decision was invoked against Venezuela in Mobil Investment Canada Inc. ${ }^{73}$ This is referred to not only because of citation of Metalclad but also because one of the arbitrators was Professor Philippe Sands QC, who had previously roundly criticized the Metalclad decision. ${ }^{74}$ Perhaps unsurprisingly therefore, the Mobil tribunal refused to follow the Metalclad lead in relation to NAFTA Article 1105(1) and in a rather terse paragraph pointed out that the Metalclad decision had been partially set aside by the Supreme Court of British Columbia and further that the Tribunal "is not aware of any subsequent decisions which have followed the approach taken by the Metalclad Tribunal." ${ }^{75}$ It seems as if the fair and equitable treatment part of the Metalclad decision at least was by now considered unsound.

However, more recently still, the Metalclad decision was invoked in Gold Reserve Inc. ${ }^{76}$ This is one of many cases ${ }^{77}$ brought against Venezuela in the wake of the Chávez administration's endeavours to take back the country from foreign influence in the 2000 s until his death in $2013 .{ }^{78}$ The case involves the alleged failure of the Venezuelan authorities to honour gold mining concessions held by a Canadian parent company. It was not brought under the terms of NAFTA but instead under the 1998 BIT between the Government of Canada and the Government of Venezuela.

72 The dispute between the Peruvian authorities and Lucchetti was considered to have started before the bilateral investment treaty between Chile and Peru came into force and hence did not fall within its terms. Article 6 of the Peru-Chile Bilateral Investment Treaty is concerned with expropriation in similar, though not identical, terms to NAFTA Article 1110, Id. ๆ 25.

73 Mobil Investment Canada Inc. \& Murphy Oil Corp. v. Venezuela, ICSID Case No. $\mathrm{ARB}(\mathrm{AF}) / 07 / 4$.

74 Philippe Sands, supra notes 56 \& 57.

75 Mobil Investment Canada Inc. \& Murphy Oil Corp. v. Venezuela, supra note 73, 140.

76 Gold Reserve Inc. v. Bolivarian Republic of Venezuela Case, ICSID No. ARB(AF)/09/1 (2014).

77 As of July 19, 2016, there are 24 pending cases against Venezuela at ICSID alone - despite its withdrawal from the ICSID Convention in 2012. It has already faced 16 previous (concluded) cases.

78 Nicolas Kozloff, Hugo Chávez: Oil, Politics and the Challenge to the US (2007). This is one of scores of texts on Chávez published since his election as Venezuelan President in 1999. 
In a long and often difficult appraisal, ${ }^{79}$ the Tribunal eventually turns to the question of fair and equitable treatment ${ }^{80}$ and invokes the "transparency" analysis used in Metalclad. ${ }^{81}$ The Metalclad approach was approved without any reservation and certainly no mention of Justice Tysoe's unfavourable review in the Supreme Court of British Columbia, nor the adjustment to the NAFTA interpretation of the fair and equitable treatment which occurred after the Metalclad decision, nor the comments of the panel members in Mobil \& Murphy. This decision in particular demonstrates the uncertainty and volatility that can pervade arbitral decisions.

The Gold Reserve Tribunal also discussed the question of expropriation, and again invoked the Metalclad decision, ${ }^{82}$ once again without any reservations expressed about the "broadness" of that interpretation. The tribunal went on to award damages to Gold Reserve Inc. in the amount of US\$713,032,000. ${ }^{83}$

Venezuela was also on the receiving end of another huge expropriation award at the end of 2014 in Venezuela Holdings B. $V^{84}$ Here a group of Dutch parent company investors were awarded in excess of US\$1.6b as a result of a "lawful" expropriation by the Venezuelan government which was held not to have been adequately compensated in line with the terms of the Netherlands-Venezuela BIT of $1991 .{ }^{85}$ This particular award makes no mention at all of the Metalclad decision.

All these decisions were the result of disputes which went all the way to full assessment of the merits of the parties' positions and at least each party's position was fully pleaded. However, there are instances where the threat of ISDS proceedings appear, at least on the face of it, to have resulted in a "chilling" of regulatory measures without the benefit of detailed argument. The use of threatened proceedings to influence the exercise of regulatory sovereignty has caused even more disquiet, not least because it is difficult, if not impossible, to assess the extent of its influence.

One of the starkest examples of this "use" of ISDS is the 1998 Ethylcorp decision. ${ }^{86}$ Here Ethylcorp, a group of U.S. investors incorporated in Virginia, objected to the decision of the Canadian government to ban the import of methylcyclopentadienyl manganese tricarbonyl (MMT), a petroleum additive, on the grounds of public health protection. ${ }^{87}$ This restriction was brought about by the passage of the Manganese-based Fuel Additives Act of 1997.88 The Act proscribed

Occupying some $242 \mathrm{pp}$.

Metalclad Corporation v. The United Mexican States, supra note 50, 9 甲 537-615.

Id. $\llbracket 574 \& 609$.

Id. $₫ 635$.

Though the original claim was for $\$ 1,735,124,200$. Id. 15 .

84 Venezuela Holdings B.V.v. Bolivarian Republic of Venezuela, ICSID Case No. ARB/07/27 (2014).

85 Agreement on Encouragement and Reciprocal Protection of Investments (22 October 1991) between the Kingdom of the Netherlands and the Republic of Venezuela.

86 Ethyl Corporation v. The Government of Canada, UNCITRAL, Award on Jurisdiction 24 (June 1998), available at https://www.uncitral.org/transparency-registry/registry/ data/can/ethyl_corporation.html.

87 Note however, that the production and use of MMT within Canada was not prohibited but this would have meant that Ethyl Corp would have had to have set up production facilities in Canada itself rather than relying on import of MMT.

88 Manganese-based Fuel Additives Act, S.C. 1997, c.11 (Can.). 
the interstate trade in, or import of, MMT for commercial purposes unless in accordance with an authorisation. However section 5 of the Act specifically forbids the authorisation of MMT for the purposes of addition to petroleum. The effect of the Act, in the view of Ethylcorp, was to deprive it of its business, since their MMT was blended into more that $95 \%$ by volume of the petroleum sold in Canada. ${ }^{89}$ Of course Ethylcorp were not alone in this in the sense that the Act banned the import and use of MMT as a petrol additive for every company operating in Canada. Hence there was no element of discriminatory practice. Nonetheless, Ethylcorp brought proceedings under the UNCITRAL rules alleging a breach of chapter 11 of the NAFTA, including an assertion that the passage of the Act contravened NAFTA rules on national treatment (Article 1102), performance requirements (Article 1106) and expropriation (Article 1110). In the decision on jurisdiction, delivered on June 24, 1998, the tribunal rejected the arguments of the Canadian government that (i) Ethylcorp had failed to observe procedural requirements related to timeliness; and, (ii) that the Act and statements relating to it, were not "measures", nor were they measures related to "investments" or "investors." 90 The tribunal went on to claim jurisdiction.

In the event, however, the merits of the claim were never addressed as the Canadian Government instead reached an out of court settlement with Ethylcorp, doubtless owing to lack of confidence that it could win on the merits in another arbitral forum. Though this response cannot be thought of as a classic regulatory chilling in that the provision was promulgated and remained in place after the challenge rather than preventing its genesis in the first place, it does illustrate that even where a public health measure is put in place for entirely bona fide public health reasons supported by sound science, the investor can nevertheless use the threat of arbitration to protect its investment. Further illustration of this tactic, albeit in a different context, can be observed in the campaign by Phillip Morris against plain packaging regulations in Uruguay and Australia. ${ }^{91}$

Thus there is plenty of precedent for the use of threats of arbitration to control regulation deemed to be economically threatening to an overseas investor. This gives rise to the question of whether regulatory measures adopted to protect public health or the environment in the European Union might potentially be open to challenge under the putative investment chapter of the TTIP by investors based in the U.S. Self-evidently the answer is yes by virtue of the mere existence of the investment chapter. However, there is an added nuance to challenges to environmental measures in the European Union since so many of them are based on the precautionary principle. It is contended that the different perceptions of this principle on both sides of the Atlantic presents an avenue of attack on regulatory measures in the European Union. Challenges to regulatory measures may be undertaken on the basis that the precautionary principle may be a disproportionate and non-scientific

89 Ethyl Corporation v. The Government of Canada, UNCITRAL, Award on Jurisdiction (24 June 1998), at I5 available at https://www.uncitral.org/transparency-registry/registry/data/can/ethyl_corporation.html.

90 Id. Canada's arguments are at 9 42-45; the Tribunal's rejection of them at 9 \% 50-96.

91 Philip Morris Brands Sàrl, Philip Morris Products S.A. \& Abal Hermanos S.A. v. Oriental Republic of Uruguay, ICSID Case No. Arb/10/7; Philip Morris Asia Limited (Hong Kong) v. The Commonwealth of Australia, UNCITRAL, PCA Case No. 2012-12. 
response which results in regulation based on fear and irrationality not on sound science. ${ }^{92}$ It is to this debate that we now turn.

\section{The Precautionary Principle - A Brief Background}

The precautionary principle is, in essence, the idea that lack of scientific uncertainty about a potentially harmful phenomenon, product or process should not, of itself, be a barrier to the taking of precautionary measures. The origins of the principle are somewhat obscure but it is generally traced back to Swedish and German environmental policies (Vorsorgeprinzip) of the 1970s. It has also been said to have been highly influential at the London Dumping Conference of the International Maritime Organisation in 1972, which gave rise to the Convention on the Prevention of Marine Pollution by Dumping of Wastes and Other Matter (MARPOL) which marked the beginning of the precautionary approach to the disposal of waste at sea. ${ }^{93}$ Certainly by 1992 the precautionary approach was a significant element of international environmental policy and was prominent in the Declaration of the United Nations Conference on the Environment and Development, 1992 (Rio Conference):

In order to protect the environment, the precautionary approach shall be widely applied by States according to their capabilities. Where there are threats of serious or irreversible damage, lack of full scientific certainty shall not be used as a reason for postponing cost-effective measures to prevent environmental degradation. ${ }^{94}$

By 1998, the precautionary principle had become part of the legal order of the European Communities by virtue of the Treaty of Amsterdam 1997, which inserted a new Article 131(2) into the Treaty on European Union; essentially the same text is now incorporated in Article 191 of the Treaty on the Functioning of the European Union which states that:

92 The precautionary principle has been described in the U.S. as a "paralyzing principle" (Cass R. Sunstein, The Paralyzing Principle, Regulation 32-37 (Winter 2002-2003)). Sunstein was later to write an entire text devoted to "debunking" the principles (CASS R. Sunstein, Laws of Fear: Beyond the Precautionary Principle (2005). However, criticism of the principle is not confined to the US; many prominent European commenters have also pointed out the irrationality and indeterminacy of the principle (see Lawrence Kogan \& Lucas Bergkamp, Trade, the Precautionary Principle, and Post-Modern Regulatory Process: Regulatory Convergence in the Transatlantic Trade and Investment Partnership 4 Eur. J. Risk Reg. 495, 499ff. (2013).

93 Kevin Stairs \& Peter Taylor, NGOs and the Legal Protection of the Oceans: A Case Study, in The International Politics of the Environment 110-41, 120ff. (Andrew Hurrell \& Benedict Kingsbury eds., 1992).

94 United Nations, Report of the United Nations Conference on the Human EnvironMENT, Stockholm, 5-16 June 1972 (United Nations publication, Sales No. E.73.II.A.14 and corrigendum), chap. I, Principle 15. 
Union policy on the environment shall aim at a high level of protection taking into account the diversity of situations in the various regions of the Union. It shall be based on the precautionary principle and on the principles that preventive action should be taken, that environmental damage should as a priority be rectified at source and that the polluter should pay. ${ }^{95}$

Unfortunately the principle itself is not further defined in the Treaty. Some clarification is contained within the official "Communication from the Commission on the precautionary principle" of $2000^{96}$ which indicates that the principle should be engaged:

... where preliminary objective scientific evaluation, indicates that there are reasonable grounds for concern that the potentially dangerous effects on the environment, human, animal or plant health may be inconsistent with the high level of protection chosen for the Community. ${ }^{97}$

However, the Communication also points out that

The precautionary principle should be considered within a structured approach to the analysis of risk which comprises three elements: risk assessment, risk management, risk communication.

The precautionary principle is particularly relevant to the management of risk. The precautionary principle, which is essentially used by decision-makers in the management of risk, should not be confused with the element of caution that scientists apply in their assessment of scientific data.

Recourse to the precautionary principle presupposes that potentially dangerous effects deriving from a phenomenon, product or process have been identified, and that scientific evaluation does not allow the risk to be determined with sufficient certainty.

The implementation of an approach based on the precautionary principle should start with a scientific evaluation, as complete as possible, and where possible, identifying at each stage the degree of scientific uncertainty. ${ }^{98}$

Thus the operation of the precautionary principle is envisaged as part of a wider risk assessment strategy where there is evidence that the risk exists, but the magnitude of that risk cannot be quantified with certainty. It is perhaps unfortunate that the term "sufficient certainty" in paragraph three of this extract receives no further elaboration particularly as it is in the response to the lack of sufficient certainty by policy and lawmakers that the controversy surrounding the precautionary principle inheres. The literature devoted to the general nature of the precautionary principle,

\footnotetext{
95 Treaty on the Functioning of the European Union (Consolidated Version), supra, note 24, art. 191(2).

96 Communication From the Commission on the Precautionary Principle, Commission of the European Communities, $\operatorname{COM}(2000) 1$ final available at http://eur-lex.europa.eu/ legal-content/EN/TXT/PDF/?uri=CELEX:52000DC0001\&from=EN (last visited Oct. 29, 2016).

$97 \quad I d .93$.

$98 \quad I d . \Uparrow 4$ (emphasis added).
} 
the disagreement about its use, role and implementation across the Atlantic, and its role within trade law is voluminous ${ }^{99}$ and the difference in transatlantic approaches to the principle is one of the sticking points in the negotiation of the TTIP itself. ${ }^{100}$

On the whole law- and policy-makers in the United States take a negative view of the precautionary principle ${ }^{101}$ and this view has affected trade relations between the United States and the European Union in the past where fundamental differences have arisen in the response to unquantified risk. The United States (often joined by Canada, but also frequently supported by Australia, Brazil and New Zealand) has tended to prefer a cost-benefit approach to risk, taking the view that this is a more rational and scientific approach to risk management. The European Union, on the other hand takes a more precautionary approach based, as its foundational treaty requires, on the precautionary principle - a concept seen as irrational, post-enlightenment and risk averse by many in North America. ${ }^{102}$ In crude terms

$99 \quad$ See e.g. Cass R. Sunstein, supra note 92; Lawrence Kogan \& Lucas Bergkamp, supra note 92; Roberto Andorno The Precautionary Principle: A New Legal Standard for a Technological Age, 1 J. Int’h Biotechnology L. 11, 11-12 (2004); Jacqueline Peel, The Precautionary Principle in Practice: Environmental Decision-Making And Scientific UnCertainty 1-24 (2005); Nicolas A. Ashford, The Legacy Of The Precautionary Principle In U.S. Law: The Rise of Cost-Benefit Analysis and Risk Assessment as Undermining Factors in Health, Safety and Environmental Protection, in IMPLEMENTATION the Precautionary Principle: Approaches from the Nordic Countries. the EU and the United States 352-78 (Nicolas de Sadeleer ed., 2007); Lawrence Kogan, What Goes Around Comes Around: How UNCLOS Ratification Will Herald Europe's Precautionary Principle as U.S. Law, 7 SANTA Clara J. InT'L L. 23 (2009); Lucas Bergkamp, Legal and Administrative Systems: Implications for Precautionary Regulation, in THE REALITY of Precaution, Comparing Risk Regulation in the United States and Europe 434-79 (Jonathan B. Weiner, Michael D. Rogers, James K. Hammit, \& Peter H. Sand eds., 2011); Elisa Vecchione, Is It Possible to Provide Evidence of Insufficient Evidence? The Precautionary Principle at the WTO, 13 CHI. J. INT'L L. 153 (2011); Elizabeth Fisher, Transnational Risks and Multilevel Regulation: A Cross-Comparative Perspective Framing Risk Regulation: A Critical Reflection, 47 CORNell InT'L L.J. 445 (2013). A search of the HeinOnline database for "The Precautionary Principle" yields 7,165 hits, more than 2000 of them in the last decade and 457 of them in the last two years alone.

100 See speech given by Celia Malmström, the EU Commissioner for Trade, to the Commissioner for Trade TACD Multi-Stakeholder Forum, Brussels, Jan. 26, 2016, http://trade. ec.europa.eu/doclib/docs/2016/january/tradoc_154173.pdf.

101 It has been suggested that the term "precautionary approach"- widely preferred in the United States - reflects a preference, rather than a binding principle, John S. Applegate, The Precautionary Preference: An American Perspective on the Precautionary Principle 6 Human \& Ecological Risk Assessment 413 (2000). Note however, that the reality of this distinction in practice has been questioned; see Nicholas A Ashford, supra note 99, at 354; see also Joachim Zander, The Application of the Precautionary Approach in Practice 268 (2010).

102 The history of the approaches to precaution on each side of the Atlantic and a comprehensive review of the recent policies in the two trading blocs may be found in Lucas Bergkamp \& Turner T. Smith, Legal and Administrative Systems: Implications for Precautionary Regulation, in The Reality of Precaution, Comparing Risk Regulation in the United States and Europe 434-79 (Jonathan B. Weiner et al., eds., 2011). A recent study of media coverage and commentary on the precautionary principle confirmed the more negative connotations associated with it in the USA, see Andrei Kirilenko et al., Computer-Assisted Analysis of Public Discourse: A Case Study of the Precautionary Principle in the US and UK Press, 46 Qual. Quant, 501 (2009). 
these two approaches may be thought of as the innocent-until-proven-guilty and guilty-until-proven-innocent models respectively. This difference in views has underpinned the protracted trade disputes between North America and Europe over the licensing of genetically modified organisms ${ }^{103}$ and the use of growth hormones in beef. ${ }^{104}$ However, despite the commonly asserted difference in approaches between North America and Europe, which has to some extent been perpetuated above, it is necessary to bear in mind that the situation is far more complex than a simple divergence of opinion across the Atlantic. Bergkamp and Smith's comprehensive analysis of the approach to precaution between the United States and the European Union is at pains to point out that both jurisdictions have embraced, and continue to embrace, precautionary regulation, ${ }^{105}$ that the extent of the precaution taken is highly dependent on the issue under discussion, ${ }^{106}$ and that each jurisdiction is at different stages of development in terms of its sophistication. However, they conclude that Europe, at least in 2013, remained the less sophisticated jurisdiction:

\begin{abstract}
We regard the current EU penchant for indiscriminate use of the precautionary principle - in place of factual support or structured analysis of why it is "worth it" to society to act in the face of uncertainty - as probably a passing phase, reflecting the current lack of sophistication by the European public, national politicians, and judges in making rational risk choices, coupled with aggressive, opportunistic special pleading to take advantage of the current situation by environmental NGOs and some sections of domestic EU industry and agriculture. ${ }^{107}$
\end{abstract}

Of course a European may justifiably express some scepticism of this conclusion in the face of U.S. attitudes to the uncertainty relating, for example, to climate change among certain influential members of the U.S. polity who ignore the science altogether in favour of leftist conspiracy theory. ${ }^{108}$

Whatever the realities of implementation, the difficulties with the precautionary principle as a concept are not scientific in origin. There is general consensus and

103 See World Trade Organisation, Disputes nos. DS291, DS292 and DS293, available at https://www.wto.org/english/tratop_e/dispu_e/dispu_status_e.htm (last visited Jun. 20, 2016).

104 Id. Disputes no. DS26 (1996-2009) and no. DS48 (1996-2011). For a European practitioner's view on the importance of maintaining food standards in the context of this dispute and the potential effect of TTIP, see Helen Dillon, Where's the Beef? 109 LAW Society GazetTe 16, https://www.lawsociety.ie/Documents/Gazette/Gazette\%202015/ updated-july2015.pdf (last visited Jun. 20, 2016).

105 Lucas Bergkamp \& Turner T. Smith, supra note 102, at 434-38.

106 Id. at 439 citing Jonathan B. Weiner \& Michael D. Rogers, Comparing Precaution in the United States and Europe, 5 J. Risk Res. 317 (2002) and Jonathan B. Weiner, Whose Precaution After All? A Comment on the Comparison and Evolution of Risk Regulatory Systems, 13 Duke J. Comp. InT'L L. 207 (2003).

107 Lucas Bergkamp \& Turner T. Smith, supra note 102, at 440.

108 See e.g. Jean-Daniel Collomb, The Ideology of Climate Change Denial in the United States, 9 Eur. J. Aм. Stud. (2014), http://ejas.revues.org/10305. See also, Republicans' Leading Climate Change Denier Tells the Pope to Butt Out of Climate Change Debate, The Guardian, Thurs, 11 June 2015, available at https://www.theguardian.com/ environment/2015/jun/11/james-inhofe-republican-climate-denier-pope-francis. 
mutual respect between U.S. and European scientists in relation to the scientific method itself, and hence in relation to the degree of uncertainty associated with a particular phenomenon, product or process. Disagreement emerges in relation to the most appropriate response to the uncertainty. A cost-benefit analysis approach places a higher premium on scientific rationality and regulation should only be imposed where a "significant risk" exists. The preference for this paradigm in the United States has been traced to Supreme Court precedent in the 1980s which "helped to ensure America's economic and technological advancement and competitiveness during the past several decades", ${ }^{109}$ and to the subsequent influence of the Reagan administration (ably led by the Speaker of the House Newt Gingrich) whose chief concern was reducing regulatory burden as part of the "Contract with America" and hence embraced cost-benefit analysis because it tends to generate a higher threshold for the imposition of regulation. ${ }^{110}$ The precautionary paradigm embraced in Europe, on the other hand, is said to have its origins in postenlightenment European philosophies, particularly those of France and Germany ${ }^{111}$ and to embody ethical and equitable principles derived from Western notions of morality and deontology. ${ }^{112}$

Hence disagreement over approaches to precaution are disagreements over doctrinal interpretation rather than over science or law as such. It is this that makes regulations based on the precautionary principle peculiarly vulnerable to attack in arbitral proceedings, since arbitrators are asked to rule, not so much on the quality of the science underpinning a regulation or even the act of regulation itself (though this is sometimes challenged), but rather the rationality of the regulatory response to that science. An investor might invite a tribunal to find that a regulatory response is not based on sound science, or is too cautious to be justifiable given the lack of sufficient scientific certainty. As such, it may amount to a lack of fair and equitable treatment, or a measure tantamount to expropriation. Challenges on these grounds under the proposed TTIP are plausible, and the next section uses a hypothetical challenge based on a current EU restriction to analyse the possibilities of success.

\section{The Neonicotinoids Restrictions in the European Union and How They Might FARE Under the Proposed TTIP Investment Protection Provisions}

An illustrative example of the operation of the precautionary principle in the European Union is to be found in regulations that implement the current partial restriction of the use of a class of chemicals known as the neonicotinoid insecticides (hereinafter neonics). Developed in the 1980s, principally by the chemical companies Bayer, Syngenta and Sumitomo Chemical, the neonics are a class of

109 Lawrence Kogan \& Lucas Bergkamp, supra note 92, at 497, citing Industrial Union Department, AFL-CIO v. American Petroleum Institute, 448 U.S. 607, 639 (1980).

110 Nicholas A. Ashford, supra note 99, at 356ff.

111 Lawrence Kogan \& Lucas Bergkamp, supra note 92, at 499.

112 UNESCO/COMEST, The Precautionary Principle $17 \mathrm{ff}$ (United Nations Educational, Scientific and Cultural Organisation 2005). 
systemic insecticides (taken up by all parts of the plants to which they are applied), which attack the central nervous systems of pest insects which feed on the plants with fatal effect, but with none of the environmental persistence or high mammalian toxicity associated with the previous pyrethrin, pyrethroid, organophosphate and organochlorine alternatives. ${ }^{113}$ The background to the imposition of the current restrictions on the use of these chemicals has been fully described elsewhere ${ }^{114}$ and only a brief summary is necessary here.

Initially, Council Directive 91/444/EEC ${ }^{115}$ (concerning the placing of plant protection products on the market) made provision for substances to be added to Annex 1 of that directive which listed "Active Substances Authorized for Incorporation in Plant Protection Products." Subsequent secondary legislation added a number of neonics to this Annex thereby permitting their use in plant products in the European Union. ${ }^{116}$ However, following accidental releases of these chemicals which resulted in the deaths of bee colonies, the use of the neonics clothianidin, thiamethoxam, imidacloprid and fipronil were subjected to additional risk assessment requirements. ${ }^{117}$ Subsequent regulatory amendments placed still further restrictions, specifically on the use of three of the more commonly used neonics, clothianidin, thiamethoxam and imidacloprid, as foliar treatments, as soil additives and in seed dressing. ${ }^{118}$

These restrictions were justified on the basis of a report, commissioned by the European Commission, ${ }^{119}$ by the European Food Safety Authority which reviewed the evidence on the effect of neonics on bee colonies. ${ }^{120}$ The evidence suggested that although the normal use of these pesticides was not lethal to bees, there was some evidence that neonics residues have the effect of interfering with the bees' navigation systems, thereby disorientating them and preventing them from returning to their

113 See United States Agency for Toxic Substances and Disease Registry, https://www.atsdr. cdc.gov/phs/phs.asp?id=785\&tid=153 (pyrethrins and pyrethroids), http://www.atsdr. cdc.gov/substances/toxchemicallisting.asp?sysid=39 (organophosphates) and http:// www.atsdr.cdc.gov/PHS/PHS.asp?id=353\&tid=62 (organochlorines) (last visited 20 June 2016).

114 Alberto Allemano, The Science, Law and Policy of Nicotinoids and Bees: A New Test Case for the Precautionary Principle, 4 Eur. J. Risk Reg. 191 (2013); Emma Downing, Bees and Neonicotinoids, House of Commons Library Briefing Paper No. 06656, (Dec. 3, 2015); Evan Jensen, Banning Neonicotinoids: Ban First, Ask Questions Later, 5 SeATTLE J. ENVTL. L. 47 (2015).

115 Council Directive 91/444/EEC, 1991 O.J. (L 230), 1.

116 Commission Directive 2006/45/EC, 2006 O.J. (L 130), 27; Commission Directive 2007/6/EC, 2007 O.J. (L 43), 13; Commission Directive 2008/116/EC, 2008 O.J. (L 337), 86.

117 Commission Directive 2010/12/EU, 2010 O.J. (L 65), 27.

118 Directive 91/444/EEC was repealed and replaced by EU Regulation (EC) No. 1107/2009 (2009 O.J. (L 309), 1), which in turn was implemented by EU Regulation (EC) No. 540/2011 (2011 O.J. (L 153), 1), the effect of which was to place further restrictions on the use of neonics. Finally EU Regulation (EC) No. 485/2013 (2013 O.J. (L 139), 12) took restrictions still further. For greater detail see Emma Downing, supra note 114, at 10.

119 Question No. EFSA-Q-2012-00556, approved on 31 May 2012.

120 European Food Safety Authority, Statement on the Findings in Recent Studies Investigating Sub-lethal Effects in Bees of Some Neonicotinoids in Consideration of the Uses Currently Authorised in Europe, 10 EFSA J. 2752 (2012). 
colonies or from indicating the sources of food to the remainder of the colony even were they able to return. The European Food Safety Authority recommended that further evidence was required in order to establish the magnitude of the risk. ${ }^{121} \mathrm{On}$ this basis the Commission, taking the precautionary approach required by Article 191 of the Treaty on the Functioning of the European Union, and explicitly referred to in EU Regulation (EC) No 1107/2009, recommended restrictions on the use of neonics.

These recommendations were viewed with some equivocation in the member states of the European Union ${ }^{122}$ and the arable farming community has protested that the restrictions on the application of neonics are significantly adversely affecting their business. ${ }^{123}$ In 2015 the National Farmers' Union successfully applied to the UK Government for an emergency lifting of the ban in three eastern counties of England, a move which was unsuccessfully challenged by Friends of the Earth. ${ }^{124}$ Perhaps unsurprisingly the chemical industry has viewed these restrictions as being an overreaction based on flawed field studies. ${ }^{125}$

The central regulation which introduced these restrictions, EU Regulation (EC) No. 1107/2009, is explicitly based on the precautionary principle. ${ }^{126}$ Article 1(4) states:

The provisions of this Regulation are underpinned by the precautionary principle in order to ensure that active substances or products placed on the market do not adversely affect human or animal health or the environment. In particular, Member States shall not be prevented from applying the precautionary principle where there is scientific uncertainty as to the risks

121 Id. at 1 (Abstract) "Further data would be necessary before drawing a definite conclusion on the behavioural effects regarding sub-lethal exposure of foragers exposed to actual doses of neonicotinoids".

122 At the March 2013 meeting of the Standing Committee of the Food Chain and Animal Health - the body with responsibility for advising the Commission on plant product safety - 27 representatives of the member states failed to reach the qualified majority vote required to recommend the restrictive proposal put before them. Thirteen countries voted in favour of the proposal, nine against, and five abstentions. A similar split occurred in a subsequent appeal. Owing to this failure, the Commission was then able to put forward its own proposal. For a more detailed discussion of the process see Emma Downing supra note 114, at 10-12.

123 See Neonicotinoid Ban Continues to Devastate OSR Crop, National Farmers Union, Press ReleAse, http://www.nfuonline.com/misc/press-centre/press-releases/neonicotinoid-ban-continues-to-devastate-osr-crop (last visited Jun. 20, 2016); see also CHARLES Scott \& Paul Bilsborrow, An INTERIM IMPACt assessment of the NeONICOTINOID SEED TREATMENT BAN ON OILSEED RAPE PRODUCTION IN ENGLAND: A REPORT FOR RURAL BUSINESS RESEARCH (Rural Business Research publications, undated), available at http://fbspartnership.co.uk/index.php?id=1530 (last visited Jun. 20, 2016). It was estimated that these restrictions cost farmers in 2015, in England alone, £2.8m in lost crops owing to cabbage flea beetle infestation, $i d$. at 8 .

$124 R$. on the Application of Friends of the Earth Limited v. Secretary of State for the Environment, Food and Rural Affairs v. National Farmers Union [2015] EWHC 3283 (Ad$\min )$.

125 Emma Downing, supra note 114, at 7.

126 See EU Regulation (EC) No. 1107/2009, 2009 O.J. (L 309), 1, Preamble clause (8), arts. $1(4)$ and 13(2). 
with regard to human or animal health or the environment posed by the plant protection products to be authorised in their territory.

The question is whether - should the TTIP come into being in anything like its current form - Bayer, Syngenta or Sumitomo could seek to challenge the restriction under the terms of the TTIP draft investment protection section ${ }^{127}$ on the basis that the restrictions represent a failure to accord fair and equitable treatment or that the restrictions represent an expropriation of property.

\section{A. Establishing Standing: InVestors, InVestments and Covered InVEstments}

Clearly the first requirement is that the said corporations are investors as defined in the TTIP. The current version of the TTIP draft investment chapter published by the EU Commission defines the term "investor" as "a natural person or a juridical person of a Party that seeks to make, is making or has already made an investment in the territory of the other Party." 128 Certainly the corporations would meet this requirement since all have offices in the United States. ${ }^{129}$ There is certainly no requirement that the nationality of the investor be defined by reference to the domicile of the parent company, though the terms of the investment chapter in the governing treaty would be relevant and could, conceivably, contain such a requirement. However, the chances of such a restrictive trade requirement successfully becoming part of a final investment text are very slim and highly unlikely to be included in the final text of the TTIP. No such requirement appears in the TPP, the CETA or any of the treaties with which the author is familiar. The TPP defines an "investor of a Party [to be] a Party, or a national or an enterprise of a Party, that attempts to make, is making, or has made an investment in the territory of another Party." 130 CETA - likely to be more representative of the final text of

See infra note 128 for further explanation of this document.

128 TTIP, Draft Chapter on Trade in Services, Investment and E-Commerce, art. 1-1(3) (q), available at $\mathrm{http} / /$ trade.ec.europa.eu/doclib/docs/2015/july/tradoc_153669.pdf (last visited Jun. 20, 2016). Note that this draft chapter is incomplete in respect of the Investment Protection provisions to be included in Section 2 and that the current version contains a placeholder at p.10 for this section. The draft investment protection section has been released as a separate document by the European Commission (http://trade. ec.europa.eu/doclib/docs/2015/september/tradoc_153807.pdf). For clarity these two documents are henceforth referred to as the "TTIP draft investment chapter" and the "TTIP draft investment protection section" respectively.

129 Syngenta is a Swiss parent company but has regional offices in Durham and Greensboro, North Carolina, as well as in Minnesota and Nebraska, United States. Similarly, Bayer, though a German parent company, has a U.S. office in Pittsburgh, Pennsylvania. In fact, Bayer's U.S. presence may be set to become even bigger with rumours of a takeover bid for the Monsanto Corporation. If permitted by the U.S. authorities this would give Bayer an estimated $40 \%$ share of the agricultural chemicals and biotech market in the U.S. alone (BBC Radio Four, Today Programme, 0620h, Wed. Sep. 7, 2016). The Sumitomo Corporation is a Japanese parent company, but the Sumitomo Corporation of the Americas has offices all over the US, including New York, Illinois, Colorado, Minnesota, Texas, California, Oregon and Washington D.C.

130 Trans-Pacific Partnership, supra, note 10, art. 9.1. 
TTIP given that the European Union is a party - is more prescriptive and defines an investor as:

... a Party, a natural person or an enterprise of a Party, other than a branch or a representative office, that seeks to make, is making or has made an investment in the territory of the other Party;

For the purposes of this definition, an enterprise of a Party is:

(a) an enterprise that is constituted or organised under the laws of that Party and has substantial business activities in the territory of that Party; or

(b) an enterprise that is constituted or organised under the laws of that Party and is directly or indirectly owned or controlled by a natural person of that Party or by an enterprise mentioned under paragraph (a) $)^{131}$

In general arbitral panels have taken a generous view of relationships between subsidiary and parent companies in establishing the existence of "substantial business activities" 132 and it is unlikely that the corporations would have any difficulty in establishing their status as U.S. investors for the purposes of the TTIP.

It would then need to be established that the licensing and marketing of neonics in the European Union is a covered investment.

A "covered investment" is "an investment which is owned, directly or indirectly, or controlled, directly or indirectly, by investors of one Party in the territory of the other Party made in accordance with applicable laws ..."133 The fact that the imposition of the neonics restrictions would obviously predate the TTIP (should it ever be signed and ratified) would not be a barrier since the definition of "covered investment" includes an investment "whether made before or after the entry into force of this Agreement." 134 Thus the definition of a covered investment would be retrospective and cover all the contentious trade disputes extant at the time of the signing of TTIP (not only the neonics dispute but other, more long-standing ones such as the beef hormones and GMOs disputes). ${ }^{135}$

An "investment" is defined in the TTIP draft investment protection section as:

... every kind of asset which has the characteristics of an investment, which

includes a certain duration and other characteristics such as the commitment of

131 Comprehensive Economic and Trade Agreement, supra, note 38, art 8.1. (emphasis in original).

132 Seee.g. Waste Management Inc. v. United Mexican States, ICSID Case No.ARB(AF)/00/3, Award (Apr. 30, 2004). This was decided under NAFTA art. 1113(2) which requires that an investor establish "... substantial business activities in the territory of the Party under whose law it is constituted or organized." The tribunal stated at 90 that "There is no hint of any concern that investments are held through companies of non-NAFTA States, if the beneficial ownership at relevant times is with a NAFTA investor" (emphasis added). This fairly low threshold for Party investor status was further bolstered at $₫ 83$ where the tribunal held that " ... there is no trace of a requirement that the investment itself have the nationality of that Party either at the time it was acquired or at the time the conduct complained of occurs."

133 TTIP, draft investment protection section, supra note 128, art. (x1), p. 1.

134 Id.

135 Supra notes $103 \& 104$. 
capital or other resources, the expectation of gain or profit, or the assumption of risk. Forms that an investment may take include:

a) an enterprise;

b) shares, stocks and other forms of equity participation in an enterprise;

c) bonds, debentures and other debt instruments of an enterprise;

d) a loan to an enterprise;

e) any other kinds of interest in an enterprise;

f) an interest arising from:

i) a concession conferred pursuant to domestic law or under a contract, including to search for, cultivate, extract or exploit natural resources,

ii) a turnkey, construction, production, or revenue-sharing contract, or

iii) other similar contracts;

g) intellectual property rights;

h) any other moveable property, tangible or intangible, or immovable property and related rights;

i) claims to money or claims to performance under a contract;

For greater certainty, 'claims to money' does not include claims to money that arise solely from commercial contracts for the sale of goods or services by a natural person or enterprise in the territory of a Party to a natural person or enterprise in the territory of the other Party, domestic financing of such contracts, or any related order, judgment, or arbitral award.

Returns that are invested shall be treated as investments and any alteration of the form in which assets are invested or reinvested shall not affect their qualification as investments. ${ }^{136}$

It is submitted that the corporations would have little difficulty in establishing ownership or control of investments in Europe under many of these headings (which are in any case not exhaustive) by virtue of their supply and licensing of insecticides in the European Union. In any event it has been noted elsewhere that "there has been a tendency to extend the meaning of investment in treaties." 137

Article 1 of the TTIP draft investment protection section sets the jurisdictional scope of the section relating to investment protection as including "(i) covered investments, and (ii) investors of a Party in respect of a covered investment as regards any treatment that may affect the operation of such investment."138 Interpretation of the term "any treatment that may affect ... investment" by a court or tribunal would probably be undertaken by reference to principles of international investment law, where a measure (such as the neonics restriction) imposed by a government must have a "legally significant connection" to an investor. ${ }^{139}$ This

136 TTIP draft investment protection section, supra note 128, art. (x2), p.1.

137 Muthucumaraswamy Sornarajah, International Law on Foreign InVestment, 16 (3d ed., 2010).

138 TTIP draft investment protection section, supra note 128, art. 1, p. 3.

139 See e.g. Bilcon v. The Government of Canada, UNCITRAL, PCA Case No. 2009-04, Award on Jurisdiction and Liability, $\mathbb{2} 240$ (Mar. 17, 2015). 
requirement derives largely from the interpretation of Article 1101 of the NAFTA ${ }^{140}$ and is said to have arisen to limit claims to principal investors only and to prevent ancillary claims by suppliers, subcontractors and so forth. ${ }^{141}$ Arguably, however, the draft TTIP criteria of "any treatment" by a host Party is far wider than the equivalents in NAFTA, CETA and TPP which relate to "measures ... adopted or maintained"142 and it is submitted that the corporations would have little difficulty in establishing the requisite legal significance since the restrictions imposed by the EU Commission are aimed specifically at neonicotinoid pesticides, Further, it would be open to the corporations to request that a tribunal view their submissions de novo on the basis that previous arbitral decisions have stated that a case-by-case analysis of whether measures (or, presumably, "treatments") have legal significance for the investors is appropriate. ${ }^{143}$

Having established standing it would then be necessary for the corporations to establish that the EU Regulations restricting the use of neonics in some way contravenes the investment protection measures guaranteed by Chapter II, section 2 of the TTIP. This section contains provisions relating to investor treatment and protection. Previous arbitration decisions suggest that a challenge to the neonics restrictions are most likely to succeed under the fair and equitable treatment and expropriation provisions.

\section{B. FAIR AND EQUiTABLE TREATMENT}

Fair and equitable treatment provisions in the TTIP draft investment protection section appear at Article 3, paragraph 2 and state that:

A Party breaches the obligation of fair and equitable treatment ... where a measure or a series of measures constitutes:

(a) denial of justice in criminal, civil or administrative proceedings; or

(b) fundamental breach of due process, including a fundamental breach of transparency and obstacles to effective access to justice, in judicial and administrative proceedings; or

(c) manifest arbitrariness; or

(d) targeted discrimination on manifestly wrongful grounds, such as gender, race or religious belief; or

140 Which sets the scope of the investment chapter of NAFTA as limited to "measures adopted or maintained by a Party relating to: (a) investors of another Party; (b) investments of investors of another Party in the territory of the Party ..." [emphasis added]. Article 8.2. (1) of the CETA and Article 9.2 of the TPP both set an almost identical scope to that in Article 1101 of the NAFTA. It is suggested that the phrase "any treatment that may affect the operation of [investors/investments]" in the draft TTIP investment chapter is equivalent to "measures adopted or maintained ... relating to [investors/investments] " in NAFTA, CETA and TPP.

141 Id. citing Methanex Corporation v. United States of America, UNCITRAL, First Partial Award, \ 147 (Aug. 7, 2002).

142 For extensive discussion of the notion of "measures ... adopted or maintained" in the context of NAFTA, Article 1101 see Ethyl Corporation v. The Government of Canada, supra note 86 , ๆๆ 65-69.

143 Bilcon v. The Government of Canada, UNCITRAL, PCA Case No. 2009-04, Award on Jurisdiction and Liability, $\uparrow 240$ (Mar. 17, 2015). 
(e) harassment, coercion, abuse of power or similar bad faith conduct; or

(f) a breach of any further elements of the fair and equitable treatment obligation adopted by the Parties in accordance with paragraph 3 of this Article. ${ }^{144}$

Paragraph 4 further extends the provision:

When applying the above fair and equitable treatment obligation, a tribunal may take into account whether a Party made a specific representation to an investor to induce a covered investment, that created a legitimate expectation, and upon which the investor relied in deciding to make or maintain the covered investment, but that the Party subsequently frustrated. ${ }^{145}$

The first point to note about this provision is that, unlike the equivalent provision in the NAFTA, ${ }^{146}$ it makes no reference to international law. Hence, unlike the numerous NAFTA decisions involving fair and equitable treatment which have been constrained to treat it as an element of the minimum standard of treatment doctrine in international trade law, ${ }^{147}$ the fair and equitable treatment standard in the current version of TTIP may represent "an independent treaty standard that has a distinct and separate meaning from the minimum standard of treatment."148 The question is whether that distinct and separate meaning could be interpreted by a tribunal as imposing higher standards of treatment on host parties than required under international law.

It is possible that the corporations could argue, based on the uncertainty of the evidence that led to the imposition of the neonics restrictions, that the imposition amounts to manifest arbitrariness. ${ }^{149}$ Admittedly this would be difficult if solely reliant on demonstrating that the restrictions were capriciously imposed, though counsel for the corporations may get a little further if they attempted to equate arbitrariness with inconsistency, unpredictability and irrationality, thereby appealing to the vast body of opinion that suggests that adherence to the precautionary

44 TTIP draft investment protection section, supra note 128, art. 3, p. 4.

145 Id.

146 The NAFTA states that: Each Party shall accord to investments of investors of another Party treatment in accordance with international law, including fair and equitable treatment and full protection and security [North American Free Trade Agreement, supra note 9, art. 1105(1)] (emphasis added). The significance of this reference to international law for the interpretation of Article 1105(1) (which was at the heart of the Metalclad decision, supra note 50) has been extensively discussed by Patrick Dumberry, The Meaning of the Fair and Equitable Treatment Standard under NAFTA Article 1105 in Light of the General Rules of Treaty Interpretation, 16 INT. A.L.R. 121 (2010).

147 See Bilcon v. The Government of Canada, UNCITRAL, PCA Case No. 2009-04, Award on Jurisdiction and Liability, $9427 \mathrm{ff}$ (Mar. 17, 2015). Here the tribunal reviews the international law on minimum standards of treatment and how the concept of fair and equitable treatment fits within it. The Waste Management tribunal decision in particular, supra note 69 , figures large in its analysis.

148 Partick Dumberry, supra note 146, at 121. (emphasis in original).

149 Arbitrary: 1. Dependent on will or pleasure ... 2. Based on mere opinion or preference as opposed to the real nature of things; capricious, unpredictable, inconsistent. THE NEW Shorter Oxford English Dictionary, 107 (Lesley Brown, ed., vol. 1 A-M, 1993). 
principle is indeed irrational, unpredictable, anti-scientific and, thus, arbitrary. This argument could be further bolstered by the "legitimate expectation" provision in Article 3, paragraph 4 if it could be argued that the initial inclusion of neonics in Annex 1 of Directive 91/444/EEC and then EU Regulation (EC) No. 1107/2009 amounted to a "specific representation", which the subsequent restrictions - based as they were on the precautionary principle - "frustrated." 150 In the Bilcon v. Canada arbitration, the Delaware-based investors successfully persuaded the tribunal that a panel charged with assessing the potential environmental effects of a quarrying operation on cetaceans in the adjacent ocean, had overemphasised "community core values" to the detriment of its statutory duty to conduct "a "likely significant effects after mitigation' analysis to the whole range of potential project effects" as required by Canadian law. ${ }^{151}$ This amounted to a "problematic" and "unique" approach, which, when combined with the inducement to invest, fell below the minimum standard of treatment that the investor was entitled to expect and amounted to a frustration of their expectation vis-à-vis their investment. ${ }^{152}$ It is suggested that the decision of the EU Commission to propose its own restrictions on the use of neonics, against the background of the failure of the Standing Committee of the Food Chain and Animal Health to reach the required qualified majority, and the equivocation about the quality of the evidence available by the European Food Standards Agency, could also be characterised as a failure to provide fair and equitable treatment. The crucial difference of course between this and the Bilcon scenario is that the Commission could point out that their decision was based on the EU legal requirement to operate according to the precautionary principle and to "err on the side of safety." The counter to that argument is to point to the inherent unpredictability of the implementation of the precautionary principle which could lead to different but equally plausible expectations on both sides as to the most appropriate regulatory response. It is suggested that in the event of intercession by an arbitral tribunal it is by no means certain whose expectation would carry the argument. The tribunal would be asked, in effect, to engage in a proportionality assessment, but without necessarily having to conform to the usual boundaries of that public law principle. In short, the outcome of such an argument is a long way short of a foregone conclusion.

\section{EXPROPRIATION}

So far as is relevant for present purposes, Article 5 of the TTIP draft investment protection section makes the following provision:

150 See Bilcon v. The Government of Canada, UNCITRAL, PCA Case No. 2009-04, Award on Jurisdiction and Liability, 444 (Mar. 17, 2015). The tribunal examines the nature of the conduct required, inter alia, to frustrate a legitimate expectation, and concludes that " ... there is no requirement in all cases that the challenged conduct reaches the level of shocking or outrageous behaviour." The [Waste Management] formulation also recognises the requirement for tribunals to be sensitive to the facts of each case, the potential relevance of reasonably relied-on representations by a host state, and a recognition that injustice in either procedures or outcomes can constitute a breach.

151 Id. ๆ⿻ 450-52.

152 Id. 9 ๆ $446-54$. 
Neither Party shall nationalize or expropriate a covered investment either directly or indirectly through measures having an effect equivalent to nationalisation or expropriation (hereinafter referred to as 'expropriation') except:

(a) for a public purpose;

(b) under due process of law;

(c) in a non-discriminatory manner; and

(d) against payment of prompt, adequate and effective compensation. ${ }^{153}$

This text is supplemented by Annex 1 - which expands on the interpretation of article 5 - and includes a definition of direct and indirect expropriation, ${ }^{154}$ as well as indicating that, in determining whether a measure is an indirect appropriation, account is to be taken of the economic impact, duration and character of the measure ${ }^{155}$ Most significant for this discussion is the provision that:

For greater certainty, except in the rare circumstance when the impact of a measure or series of measures is so severe in light of its purpose that it appears manifestly excessive, non-discriminatory measures of a Party that are designed and applied to protect legitimate public welfare objectives, such as the protection of public health, safety, environment or public morals, social or consumer protection or promotion and protection of cultural diversity do not constitute indirect expropriations. ${ }^{156}$

The regulations restricting the use of neonics comply with the criteria in paragraphs (a) to (c) of Article 5, but since (presumably) the corporations have not been compensated in respect of the restrictions on neonics, then the measures could amount to an expropriation of the corporations' investments under Article 5(d). Since they are clearly not a direct expropriation - not involving "[a] formal transfer of title or outright seizure" 157 - then they can only amount to an indirect expropriation as "substantially depriv[ing] the investor of the fundamental attributes of property in its investment, including the right to use, enjoy and dispose of its investment, without formal transfer of title or outright seizure." 158

However, since these measures have clearly been "designed and applied to ... the protection of [the] environment," then they should be safe from attack as indirect expropriation measures, in reliance on Annex 1, paragraph (3) unless it could be shown that the restrictions are "so severe in light of [their] purpose that [they appear] manifestly excessive." This is potentially the avenue by which the precautionary basis of the measures could be attacked by the investor corporations. Again, the paucity of the evidence of cause and effect between the normal use of neonics and the effect on bee geolocation could be used to argue that the regulatory response is manifestly excessive and hence tantamount to an indirect expropriation.

\footnotetext{
TTIP draft investment protection section, supra note 128, art. 5.

Id. annex $1, \boldsymbol{q} 1$.

Id. $\uparrow 2$.

Id. $\uparrow 3$ (emphasis added).

Id. annex $1, \uparrow 1(\mathrm{a})$.

${ }_{158} I d$. annex 1, ๆ $1(\mathrm{~b})$
} 
In the Bilcon case - one of the few arbitral cases where the precautionary principle was at issue - the investors argued that the environmental assessment panel had: used "a distorted precautionary principle" 159 ; "an improperly expansive precautionary principle"160; of "appl[ying] a patently incorrect definition [of the precautionary principle]." had demanded too high a level of scientific certainty "to prove that the project would not cause any environmental damage, rather than recognising that uncertainty may be inevitable [and] cannot paralyze a project." ${ }^{\text {"162 }}$ In other words the investors' view of the precautionary principle was that scientific uncertainty should not stand in the way of granting permission for an activity - a reversal of the conventional application of the principle, certainly as it would be applied in the European Union. However the tribunal itself chose not to address this issue directly and the words "precautionary principle" appear nowhere - not even in allusory terms - in the justification for their final decision. ${ }^{163}$ This avoidance of the issue is not explained but it would not be surprising if the arbitrators chose to evade the issue altogether - given its indeterminacy - where other, less contentious grounds for the decision existed.

Before leaving the Bilcon case, it would be remiss not to refer to the tribunal's extensive discussion of the role of "human concerns"164 (which includes environmental effects) and the need to avoid "regulatory chill" in its reasoning. ${ }^{165}$ The tribunal reminded "consumers" of their decision of:

... the Tribunal's view that under NAFTA, lawmakers in Canada and the other NAFTA parties can set environmental standards as demanding and broad as they wish and can vest in various administrative bodies whatever mandates they wish. Errors, even substantial errors, in applying national laws do not generally, let alone automatically, rise to the level of international responsibility vis-à-vis foreign investors. The trigger for international responsibility in this particular case was the very specific set of facts that were presented, tested and established through an extensive litigation process.

This view - particularly the first sentence - were it to become universal among arbitrators (of which, of course, there is no guarantee given the absence of the doctrine of stare decisis from tribunal decisions), should be of some comfort to those concerned with environmental protection and regulatory chill. The difficulty, however, in applying this approach the context of the precautionary principle lies in the very indeterminacy of the concept in international law. Despite the Tribunal's words, it is likely that investors in future disputes will still be able to attack precautionary decisions on the basis of "distortion", "improper expansive[ness]" and "patent incorrect[ness]" in the same way as the investors in Bilcon itself, and hence such decisions may still rise to the level of "international responsibility" and thereby

159 Bilcon v. The Government of Canada, UNCITRAL, PCA Case No. 2009-04, Award on Jurisdiction and Liability, $\uparrow 201$ (Mar. 17, 2015).

160 Id. ๆ⿻ $214 \& 372$.

161 Id. $\ 380$.

162 Id. 9500.

163 Id. ๑ף 685-731.

164 Id. $\uparrow 736$.

165 Id. १ๆ $737 \mathrm{ff}$. 
threaten the environmental sovereignty of host states. Clearly, the Bilcon tribunal's words above have not deterred the investors in the Lone Pine arbitration ${ }^{166}$ - still ongoing at the time of writing - who have accused the government of Quebec of:

the arbitrary, capricious, and illegal revocation of the Enterprise's valuable right to mine for oil and gas under the St. Lawrence River by the Government of Quebec without due process, without compensation, and with no cognizable public purpose. ${ }^{167}$

This was in response to Quebec's imposition of a moratorium on fracking - a precautionary measure with many counterparts in Europe.

\section{THE ENVIRONMENT CHAPTER IN THE TTIP}

The final draft of the environment chapter of the TTIP is not yet available, ${ }^{168}$ so it is not yet possible to ascertain the extent to which precautionary measures may be offered protection. Thus far, no specific protection of the precautionary principle has been included in any of the draft texts which have been released. There is provision for the precautionary principle - though not under that name - in the CETA, which is the only other "North American" free trade agreement which the European Union has entered into thus far. ${ }^{169}$ There are two specific chapters in the CETA related to environmental protection - Chapter 24 (Trade and the Environment) and Chapter 25 (Trade and Sustainable Development). Under Article 24.8.2:

The Parties acknowledge that where there are threats of serious or irreversible damage, the lack of full scientific certainty shall not be used as a reason for postponing cost-effective measures to prevent environmental degradation. ${ }^{170}$

This apparent protection for the precautionary principle suggests a model of precaution much closer to the North American cost-benefit approach ${ }^{171}$ than the EU notion of precaution which underpins the neonics restrictions. The requirements for either "serious" or "irreversible" damage closely reflects the text of Principle 15 of the Rio Declaration, ${ }^{172}$ with no apparent concession to the more precautionary approach commonly referenced in European law. ${ }^{173}$ Should the same text appear in the TTIP (assuming the negotiations do reach a conclusion), it is suggested that they would not necessarily protect the Commission's regulatory precautions on neonics

166 Lone Pine Resources Inc. v. The Government of Canada, UNCITRAL, Notice of Arbitration, Sept. 6, 2013, available at http://www.italaw.com/cases/1606.

167 Id. $\uparrow 11$.

168 Strictly speaking a draft is available (http://trade.ec.europa.eu/doclib/docs/2015/november/ tradoc_153923.pdf) entitled Trade and Sustainable Development. However, there is not yet a "Trade and Environment" Chapter similar to the equivalents in the CETA and TPP.

169 Some references to "precaution" do appear in the early 1600 pages of the agreement, but these are exclusively related to intellectual property protection in chapter 20.

170 Comprehensive Economic and Trade Agreement, supra, note 38, art. 24.8.2.

171 See supra notes 101 to 107 and associated text.

172 United NATIONS, supra note 94.

173 Communication from the Commission, supra note 96. 
since it is eminently possible to argue that the threat posed by neonics - based on the available evidence - is neither serious nor irreversible.

\section{E. INFLUENCE OF THE EU COMMISSION'S PROPOSED INDEPENDENT ARBITRAL TRIBUNAL}

One of the most controversial aspects of the TTIP negotiations over the investment chapter is the perception that unaccountable arbitrators in investment-state disputes will be in a position to dictate to sovereign states over matters which have traditionally been considered the sole preserve of national regulatory authorities or legislators. To address this concern the European Commission has issued - as part of the draft investment services document - proposals for the setting up of an independent arbitral tribunal and appeal tribunal for Europe. ${ }^{174}$ These proposals are closely modelled on the WTO Appellate body and it is hoped ${ }^{175}$ that this will address the criticisms raised in the past, ${ }^{176}$ the "fundamental lack of trust" 177 in arbitral tribunal decisions, and in particular the vexed questions of lack of legal training, ${ }^{178}$ independence, ${ }^{179}$ the lack of avenues for appeal, ${ }^{180}$ and the lack of transparency. ${ }^{181}$

However, whilst these measures (in the perhaps unlikely event that they are accepted by the United States) will doubtless improve the quality and legitimacy of arbitral decisions, it is questionable whether they would affect an assessment of the precautionary principle in any substantive sense. The tribunal will still be an investment arbitration tribunal rather than a court of general jurisdiction and, as such, will be principally bound by the TTIP text. Despite its more "legitimate" credentials the new tribunal will still be required to straddle the uncomfortable divide between private and public law imperatives (in a way that is not required of the WTO panels on which it is modelled) and make compromises between them - in short, no different to the exercise undertaken by existing ICSID and UNCITRAL tribunals.

As already discussed, what is known of the TTIP text already offers ample potential for challenges to regulations based on the precautionary principle. This potential, it is suggested, will not be materially affected by the make-up or procedures of the tribunal panel itself.

174 TTIP draft investment protection section, supra note 128, arts. 9-30.

175 See Commission proposes new Investment Court System for TTIP and Other EU Trade and Investment Negotiations, European Commission press release of Sept. 16, 2015, IP 15/5651.

176 Mojtaba Dani \& Afshin Akhtar-Khavari, The Uncertainty of Legal Doctrine in Indirect Expropriation Cases and the Legitimacy Problems of Investment Arbitration, 22 WIDENER L. REv. 1, 3 (2016).

177 Supra note 175 per Celia Wallström, EU Trade Commissioner.

178 TTIP draft investment protection section, supra note 128, art. 9.

$179 I d$. arts. $9 \& 11$.

180 Id. arts. $10 \& 29$.

181 Id. art. 18. 


\section{CONCLUSION}

As this paper was being completed, the TTIP negotiations entered their $15^{\text {th }}$ round ${ }^{182}$ against the backdrop of recent demonstrations in Germany against both TTIP and CETA. ${ }^{183}$ The EU Commission will no doubt be even more conscious of the need to reassure European citizens that TTIP will not undermine national sovereignty - a message that has assumed even greater importance since the citizens of the United Kingdom voted in favour of "Brexit" in a referendum in July 2016. The "Leave" campaign in Britain made much of the need to "regain sovereignty" from the European Union, ${ }^{184}$ so that questions of national sovereignty are now, more than ever at the forefront of politicians' minds in the EU.

Where environmental sovereignty is concerned the text of the TTIP includes, at first sight, quite strongly worded provisions to permit nation states to maintain and enhance environmental protection. However, very similar provisions to these appear in other investment and trade agreements but they have not necessarily prevented investors from seeking compensation for the loss of their investment (or the value of it) as a result of local, regional or national measures designed to protect the environment or public health. Such claims have invariably been based on the fair and equitable treatment principle and/or on the basis that the measures represent measures tantamount to (indirect) exropriation. It is also the case that such claims do not necessarily need to reach the merits stage in order to bring about the desired effect as illustrated in the Ethyl Corp decision discussed above.

The current text of the TTIP does not suggest that it is likely to be significantly more resilient to such claims than many of its forbears. In fact, given that so much of the regulation in environmental matters and public health in the European Union is based on a version of the precautionary principle which is far more "precautionary" than envisaged in principle 15 of the Rio Declaration, investor claims which seek to attack its rationality are probably more likely.

Of course the final version of the TTIP may contain explicit protection for the precautionary principle, but, if this merely repeats the provision in CETA, then it is unlikely to prevent claims based on equivocal scientific evidence such as the restrictions currently in place for neonicotinoid pesticides. Moreover, the provision of a bespoke tribunal and appeal system within TTIP may not necessarily make claims founded on the irrationality of regulatory responses to the precautionary principle any less plausible or any more likely to fail.

Investment protection agreements have the potential to enhance environmental protection if they encourage greater transparency of regulation by the host state so that the investor is certain about the regulatory environment into which they are entering and know the risks. However, the approach of investment tribunal panels themselves needs to change in order to take a broader view of purposes

182 EU and US Trade Negotiators Seek to Get TTIP Talks back on Track, ThE GUARDIAn, Fri, Sept. 30, 2016, https://www.theguardian.com/business/2016/sep/30/ttip-eu-and-ustrade-negotiators-seek-to-get-talks-back-on-track.

183 Protests in Germany Against Transatlantic TTIP and CETA Trade Deals, BBC News ONLINE, Sept. 17, 2016, http://www.bbc.co.uk/news/world-europe-37396796.

184 Though admittedly this was mostly in the context of the rather narrow question of the freedom of movement of persons. 
of arbitration in an era of climate change, loss of biodiversity and the need to preserve ecosystem services. It can no longer be appropriate merely to consider the private property rights of investors as the primary consideration. The public interest in environmental quality and the need to adapt to environmental pressures by sovereign authorities must play a greater part. In the long run this is in the interests of investors also. However, it is the elected sovereign authorities who must be permitted the final word in how this is brought about rather than corporate entities who primary purpose is the generation of profit. 